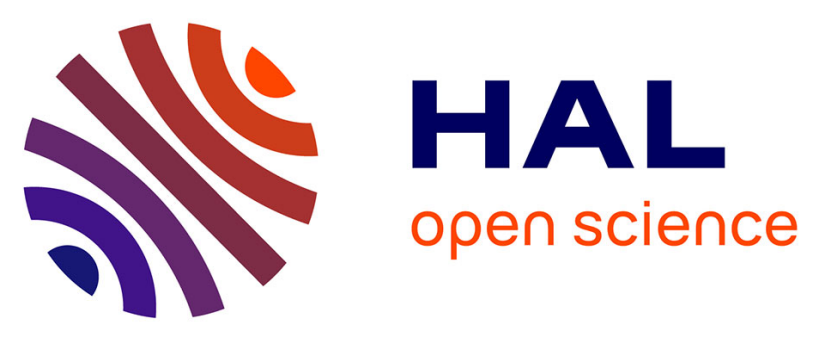

\title{
Pancreatoduodenectomy as a source of human small intestine for Ussing Chamber Investigations and comparative studies with rat tissue
}

Iain Stuart Haslam, Derek A O’Reilly, David J Sherlock, Ambareen Kauser, Chris Womack, Tanya Coleman

\section{To cite this version:}

Iain Stuart Haslam, Derek A O'Reilly, David J Sherlock, Ambareen Kauser, Chris Womack, et al.. Pancreatoduodenectomy as a source of human small intestine for Ussing Chamber Investigations and comparative studies with rat tissue. Biopharmaceutics \& Drug Disposition, 2011, 32 (4), pp.210. 10.1002/bdd.751 . hal-00624421

\section{HAL Id: hal-00624421 \\ https://hal.science/hal-00624421}

Submitted on 17 Sep 2011

HAL is a multi-disciplinary open access archive for the deposit and dissemination of scientific research documents, whether they are published or not. The documents may come from teaching and research institutions in France or abroad, or from public or private research centers.
L'archive ouverte pluridisciplinaire HAL, est destinée au dépôt et à la diffusion de documents scientifiques de niveau recherche, publiés ou non, émanant des établissements d'enseignement et de recherche français ou étrangers, des laboratoires publics ou privés. 


\section{Pancreatoduodenectomy as a source of human small intestine for Ussing Chamber Investigations and comparative studies with rat tissue}

\begin{tabular}{|c|c|}
\hline Journal: & Biopharmaceutics \& Drug Disposition \\
\hline Manuscript ID: & BDD-10-0113.R1 \\
\hline Wiley - Manuscript type: & Original Papers \\
\hline $\begin{array}{r}\text { Date Submitted by the } \\
\text { Author: }\end{array}$ & 26-Jan-2011 \\
\hline Complete List of Authors: & $\begin{array}{l}\text { Haslam, Iain; AstraZeneca } \\
\text { O'Reilly, Derek; North Manchester General Hospital, Department of } \\
\text { Surgery } \\
\text { Sherlock, David; North Manchester General Hospital, Department of } \\
\text { Surgery } \\
\text { Kauser, Ambareen; North Manchester General Hospital, Department } \\
\text { of Surgery } \\
\text { Womack, Chris; AstraZeneca, CDxT } \\
\text { Coleman, Tanya; Astrazeneca, DMPK }\end{array}$ \\
\hline Keywords: & Ussing Chamber, Absorption, pancreatoduodenectomy \\
\hline Abstract: & $\begin{array}{l}\text { A clear understanding of oral drug absorption is an important } \\
\text { aspect of the drug development process. The permeability of drug } \\
\text { compounds across intact sections of small intestine from numerous } \\
\text { species, including man, has often been investigated using modified } \\
\text { Ussing Chambers. The maintenance of viable, intact tissue is } \\
\text { critical to the success of this technique. This study therefore aimed } \\
\text { to assess the viability and integrity of tissue from patients } \\
\text { undergoing pancreatoduodenectomy, for use in cross-species } \\
\text { Ussing chamber studies. Electrical parameters (potential } \\
\text { difference; mV, short-circuit current; } \mu A \text { A. } \mathrm{cm}^{-2} \text { and resistance; } \\
\Omega / \mathrm{cm}^{2} \text { ) were monitored over the duration of each experiment, as } \\
\text { was the permeability of the paracellular marker atenolol. The } \\
\text { permeability values (Papp; } \mathrm{cm} / \mathrm{s} \times 10^{-6} \text { ) for a training-set of } \\
\text { compounds, displaying a broad range of physicochemical properties } \\
\text { and known human fraction absorbed values, were determined in } \\
\text { both rat and human jejunum, as well as Caco-2 cell } \\
\text { monolayers. Results indicate that human jejunum sourced from } \\
\text { pancreatoduodenectomy remained viable and intact for the duration } \\
\text { of experiments. Permeability values generated in rat and human } \\
\text { jejunum correlate well ( } \mathrm{R}^{2}=0.86 \text { ), however the relationship } \\
\text { between permeability in human tissue and Caco-2 cells was } \\
\text { comparatively weak ( } \mathrm{R}^{2}=0.58 \text { ). Relating permeability to known } \\
\text { human fraction absorbed (hFabs) values results in a remarkably } \\
\text { similar relationship to both rat and human jejunum Papp values. } \\
\text { It can be concluded that human jejunum sourced from } \\
\text { pancreatoduodenectomy is a suitable source of tissue for Ussing }\end{array}$ \\
\hline
\end{tabular}



permeability and hFabs is comparable with results reported using alternative test compounds.

\section{SCHOLARONE Manuscripts}




\section{BDD-10-0113-R1}

Pancreatoduodenectomy as a source of human small intestine for Ussing Chamber Investigations and comparative studies with rat tissue

Iain S Haslam', Derek A O’Reilly ${ }^{2,3}$, David J Sherlock ${ }^{2}$, Ambareen Kauser², Chris Womack ${ }^{4}$, Tanya Coleman ${ }^{1}$

${ }^{1}$ Drug Metabolism and Pharmacokinetics, AstraZeneca Research \& Development, Alderley Park, Macclesfield, Cheshire, SK10 4TG

${ }^{2}$ Department of Surgery, North Manchester General Hospital, Pennine Acute Hospitals Trust, Delaunays Road, Manchester, M8 5RB

${ }^{3}$ Cancer Studies Research Group, The University of Manchester, Manchester Academic Health Science Centre, Manchester, UK.

${ }^{4}$ CDXT, AstraZeneca, Alderley Park, Macclesfield, Cheshire, SK10 4TG 


\section{BDD-10-0113-R1}

Running Title: Ussing Chamber investigations using excised human intestine

\section{Corresponding Author:}

Dr Iain Haslam

Drug Metabolism and Pharmacokinetics

AstraZeneca Research and Development

Alderley Park

Macclesfield

SK10 4TG

Phone: 0161233057

iain.haslam@astrazeneca.com 


\title{
BDD-10-0113-R1
}

\begin{abstract}
.
A clear understanding of oral drug absorption is an important aspect of the drug development process. The permeability of drug compounds across intact sections of small intestine from numerous species, including man, has often been investigated using modified Ussing Chambers. The maintenance of viable, intact tissue is critical to the success of this technique. This study therefore aimed to assess the viability and integrity of tissue from patients undergoing pancreatoduodenectomy, for use in cross-species Ussing chamber studies. Electrical parameters (potential difference; $\mathrm{mV}$, short-circuit current; $\mu \mathrm{A} . \mathrm{cm}^{-2}$ and resistance; $\Omega / \mathrm{cm}^{2}$ ) were monitored over the duration of each experiment, as was the permeability of the paracellular marker atenolol. The permeability values (Papp; $\mathrm{cm} / \mathrm{s} \times 10^{-6}$ ) for a training-set of compounds, displaying a broad range of physicochemical properties and known human fraction absorbed values, were determined in both rat and human jejunum, as well as Caco- 2 cell monolayers. Results indicate that human jejunum sourced from pancreatoduodenectomy remained viable and intact for the duration of experiments. Permeability values generated in rat and human jejunum correlate well $\left(\mathrm{R}^{2}=0.86\right)$, however the relationship between permeability in human tissue and Caco-2 cells was comparatively weak $\left(\mathrm{R}^{2}=0.58\right)$. Relating permeability to known human fraction absorbed (hFabs) values results in a remarkably similar relationship to both rat and human jejunum Papp values.

It can be concluded that human jejunum sourced from pancreatoduodenectomy is a suitable source of tissue for Ussing chamber permeability investigations. The relationship between permeability and hFabs is comparable with results reported using alternative test compounds.
\end{abstract}

Keywords: Ussing Chamber, absorption, drug development, pancreatoduodenectomy 


\section{BDD-10-0113-R1}

\section{Introduction}

The measurement and prediction of oral drug absorption in the early drug discovery process is a complex task fraught with interpretation difficulties resulting from species-specific interactions and the limited physiological relevance of certain in vitro tools. Cell based assays such as Caco-2 are commonly used as an up-front screening tool for indicating the permeability of candidate compounds and by extrapolation, the "absorption potential". These cells are also often used for mechanistic studies in order to identify potential interactions with efflux transporters that could limit intestinal absorption or prevent access to the site of action [1]. Preclinical pharmacokinetic (PK) studies performed during lead optimisation give the first in vivo measure of absorption and can highlight potential limitations in bioavailability caused by intestinal processes. However, the use of rat, dog and mouse species at this stage may give contrasting data, leading to significant difficulty in accurately predicting the likely situation in man.

Modified Ussing chambers have been used for some time to study the permeability and absorption potential of New Chemical Entities (NCEs) across excised sections of intact intestinal tissue. In this way, species and region specific difference in permeability, transport and metabolic capability have been identified [2-5]. The significant advantage offered by Ussing chamber studies over cultured cell lines is the maintenance of the complex cellular heterogeneity and morphology of the mammalian intestine (including crypt-villus structures), which is not entirely mimicked by the relatively homogeneous cellular monolayer of a Caco-2 system. The presence of an extended plethora of transport proteins and drug metabolising enzymes (DMEs) as well as an intact acid microclimate mucous layer adjacent to the villus tip enterocytes, results in an experimental system that gives a more complete picture regarding processes that may impact on absorption [6-8].

Pancreatoduodenectomy (Whipple's operation) was identified as a potential source of human tissue for Ussing chamber studies. Pancreatoduodenectomy is a first-line treatment for removal of tumours located in the head of the pancreas and involves the removal of the head of the 


\section{BDD-10-0113-R1}

pancreas, duodenum, gall bladder and bile duct along with a short section of jejunum [9]. The jejunum is resected to facilitate surgical reconstruction, not for therapeutic purposes and is therefore redundant for the purposes of pathological examination.

Of critical importance when using ex vivo intestinal sections in Ussing chamber investigations, is the maintenance of tissue integrity and viability. Previous studies have identified certain parameters and set limits for monitoring the health of tissue mounted in the chambers, ensuring accuracy and consistency of the results generated [10-11].

In order to confirm the utility of human tissue sourced from pancreatoduodenectomy, a key aim was therefore to assess tissue integrity following excision and transport to our laboratory. In addition, to allow cross-species comparisons and absorption predictions, the permeability of a number of compounds was assessed using Caco- 2 cells and excised rat and human jejunum (from pancreatoduodenectomy). 


\title{
BDD-10-0113-R1
}

\section{Materials \& Methods}

\begin{abstract}
Animals
Male Han Wistar rats (Harlan, UK), aged approximately 100 days and weighing 250-400 g were used in the experiments. They were kept at a room temperature of $18{ }^{\circ} \mathrm{C}$ to $22{ }^{\circ} \mathrm{C}$ and a relative humidity of $30 \%$ to $60 \%$ under a 12-hour light/dark cycle and had free access to food and tap water. The rats were allowed to acclimatise for at least one week after arrival at AstraZeneca R\&D Alderley Park.

In order to retain viability of the intestine during surgical excision blood perfusion was maintained under isofluorane (2 L/min, $5 \%$ ) anaesthesia. After abdominal incisions were made, intestinal lumens were occluded by thin cotton thread proximal to the sections of tissue taken from duodenum, jejunum, ileum and colon. The animals were then sacrificed by heart puncture under maintained anaesthesia.
\end{abstract}

A small incision was made distal to the position of the thread to allow $2 \times 20 \mathrm{ml}$ washes of icecold Kreb's bicarbonate Ringer (KBR) solution (pH 7.4) (108.0 mM NaCl, $4.7 \mathrm{mM} \mathrm{KCl}, 0.6 \mathrm{mM}$ $\mathrm{Na}_{2} \mathrm{HPO}_{4} / \mathrm{KH}_{2} \mathrm{PO}_{4}, 16 \mathrm{mM} \mathrm{NaHCO} 3,1.2 \mathrm{mM} \mathrm{MgSO}$, $1.2 \mathrm{mM} \mathrm{CaCl}_{2}, 4.9 \mathrm{mM}$ Na-Pyruvate, 5.4 $\mathrm{mM}$ Fumarate, $4.9 \mathrm{mM}$ L-Glutamate, $11.5 \mathrm{mM}$ Glucose) to remove chyme and faecal matter. The segments were placed in a chamber containing ice-cold KBR perfused with carbogen $(95 \%$ $\mathrm{O}_{2}, 5 \% \mathrm{CO}_{2}$ ) for 30 minutes.

\section{Human small intestine}

Ethical approval was granted (IRAS reference: 09/H1006/2) and tissue samples surplus to the requirements of histopathological assessment were collected from 6 individual donors, in agreement with Surgeons at North Manchester General Hospital. Human tissue samples were collected from 6 male patients, median age 59 (range, 38-68). The specimens were obtained from patients undergoing pancreatoduodenectomy to remove tumours of the head of the pancreas. None of the patients had previously undergone radio- or chemotherapy prior to surgery. 


\section{BDD-10-0113-R1}

Perfusion of the intestine was maintained until the moment of excision. Approximately $10 \mathrm{~cm}$ of small intestine was removed and immediately placed in ice-cold KBR, pre-saturated with carbogen. Staples were removed from either end of the resected tissue to allow bathing of the mucosal surface. The tissue was then transported to the laboratories at AstraZeneca. Mean time period between excision of intestinal tissue and transport to our laboratories was $88 \pm 19$ minutes.

\section{Ussing Chamber permeability experiments}

Segments of intestine, avoiding Peyer's patches, were carefully opened along the mesenteric border and pinned onto the silicon base (90\% DC Sylgard 184-base + $10 \%$ DC Sylgard 184-catalyst) of a specially designed preparation chamber containing chilled $\left(10{ }^{\circ} \mathrm{C}\right)$ KBR gassed with carbogen. The serosal layer of the rat jejunum and musculo-serosal layers of human jejunal sections were dissected off with the aid a stereo microscope (Wild M8) and a light source (Schott KL 1500).

Intestinal segments were mounted as flat sheets in a modified Ussing chamber (Harvard Navicyte). The exposed tissue surface area was $0.64 \mathrm{~cm}^{2}$ for rat tissue and $1.78 \mathrm{~cm}^{2}$ for human sections. A 4 electrode system was used for recording electrical parameters. This consisted of 2 $\mathrm{x} \mathrm{Ag} / \mathrm{AgCl}$ electrodes for potential difference (PD) measurement and $2 \mathrm{x} \mathrm{Ag} / \mathrm{AgCl}$ electrodes for current passage. Asymmetry in the PD sensing electrodes was zeroed prior to tissue mounting. Correction for the series fluid resistance was also made in assembled chambers prior to tissue mounting. A 30-40 minute equilibration period at $37^{\circ} \mathrm{C}$ was allowed prior to the addition of test compounds.

To initiate experiments, the KBR in "donor" or "receiver" wells was replaced with $5 \mathrm{ml}$ of KBR containing the test compounds $(30 \mu \mathrm{M})$ or KBR alone. Samples were removed at 30 minute intervals up to 120 minutes, for analysis by HPLC MS/MS. Fluxes were expressed as nmol. $\mathrm{cm}^{-2} . \mathrm{hr}^{-1}$ or as apparent permeability coefficients $\left(\mathrm{P}_{\mathrm{app}} ; \mathrm{P}_{\mathrm{a}-\mathrm{b}} \& \mathrm{P}_{\mathrm{b}-\mathrm{a}}\right)$ and were calculated as reported previously [10]. $\mathrm{P}_{\mathrm{a}, \mathrm{b}}$ or app is expressed in $\mathrm{cm} / \mathrm{s}$. 
As a further measure of tissue viability at the end of the experimental period and to confirm the activity of ATP-driven (energy-dependent) processes, $100 \mu \mathrm{M}$ carbachol (CCh) was added to the basolateral chamber. As has previously been established [12-13] CCh elicits an increase in Isc by stimulating chloride secretion upon binding to muscarinic acetylcholine receptors. By measuring an increase in ATP driven, CCh-stimulated chloride secretion, tissue sections can be said to have remained energically active (ATP production and hydrolysis maintained).

\section{Cell Culture}

All cell culture was performed in a class II laminar flow hood (MBSC) under aseptic conditions. Caco-2 cells were maintained in high-glucose (4500 $\mathrm{mg} \mathrm{L}^{-1} \mathrm{D}$-glucose) Dulbecco's Modified Eagle's Medium (DMEM) supplemented with foetal calf serum (10\% v/v), L-glutamine (1 mM), non-essential amino acids $(1 \% \mathrm{v} / \mathrm{v})$ and the antibiotic gentamicin $\left(30 \mu \mathrm{g} \mathrm{ml}^{-1}\right)$. Cells were maintained at $37{ }^{\circ} \mathrm{C}$ in a humidified incubator with $5 \% \mathrm{CO}_{2}$ in air. Cells were seeded onto 96well culture inserts (Transwell 3391, $4.26 \mathrm{~mm}$ diameter, $0.4 \mu \mathrm{m}$ pore size, uncoated polycarbonate filters, Costar) at high density $\left(2.42 \times 10^{5}\right.$ cells $\left./ \mathrm{cm}^{2}\right)$. Cells were grown to confluency for 14-17 days and transepithelial electrical resistance (TEER) was measured using a WPI EVOM voltohmeter (World Precision Instruments, Stevenage, Hertfordshire, UK). Typical resistance values for Caco-2 cells were $>250 \Omega . \mathrm{cm}^{2}$.

\section{Transepithelial Transport Experiments}

Automated bi-directional transepithelial transport assays were performed using a Tecan Genesis Robotic workstation. Transport assays were performed 14-17 days post-seeding. Assays were performed in HBSS (Hanks buffered saline solution) at pH 7.4 in both apical and basal compartments. Transport plates were produced to allow the unidirectional (apical-to-basal, $P_{a-b}$ and basal-to-apical, $\left.P_{b-a}\right)$ permeability of each compound $(10 \mu \mathrm{M})$. Lucifer Yellow $(100 \mu \mathrm{M})$ 
BDD-10-0113-R1

was included in the transport buffer to allow post-assay determination of paracellular permeability, measured by spectrofluorometry (485-535). The extent of apical-to-basal and basal-to-apical transport was determined by HPLC MS/MS sample analysis for each drug compound. Apparent permeability $\left(P_{a p p} ; \times 10^{-6} \mathrm{~cm} \cdot \mathrm{s}^{-1}\right)$ was calculated for each compound in the apical-to-basal $\left(P_{a-b}\right)$ direction as described previously [10].

\begin{abstract}
Materials
Cell culture media, Kreb's bicarbonate ringer (KBR) components and supplements were from Sigma (Poole, Dorset, UK), and tissue culture plastic flasks and culture plates were supplied by Costar (High Wycombe, UK). All other chemicals obtained from Sigma (Poole, Dorset, UK). All drug compounds were purchased from Sigma (Poole, Dorset, UK) or sourced from AstraZeneca's internal compound library.
\end{abstract}

\title{
Statistics
}

All data are expressed as mean \pm standard error of the mean (SEM) with $n$ representing the number of replicates in each experiment. The differences between mean data values were assessed using unpaired Student's T-tests. Tests for linear relationships between permeability values generated in the different tissue types were performed. Non-linear regressional analysis was performed to compare permeability values with known human Fabs data. All analysis performed using Prism 4 (Graphpad InStat, San Diego, California, USA). Statistical significance was reported at $\mathrm{P}<0.05$. 
BDD-10-0113-R1

\section{Results}

\section{Tissue viability and integrity}

Figure 1 displays the electrical timecourses for rat and human small intestine mounted in Ussing Chambers. At time 0 (following the 40 minute equilibration period), mean potential difference readings were $4.7 \pm 0.3 \mathrm{mV}$ and $5.7 \pm 0.5 \mathrm{mV}$ for rat and human tissue, respectively $(n=128$ and 60 separate tissue sections, respectively). Short-circuit current (Isc) was $161.8 \pm 19.2 \mu \mathrm{A} . \mathrm{cm}^{-2}$ for rat jejunum and $200.7 \pm 51.3 \mu \mathrm{A} . \mathrm{cm}^{-2}$ for human jejunum, with rat and human resistance $(\mathrm{R})$ values being $32.6 \pm 2.3 \Omega . \mathrm{cm}^{2}$ and $23.3 \pm 3.2 \Omega . \mathrm{cm}^{2}$, respectively $(n=128$ and 60 separate tissue sections). Rat potential difference (PD) showed a steady decline over the 120 minute timecourse of each experiment, ending on $59 \%$ of the initial value. Human tissue was more resistant to decreasing PD as a reduced voltage difference was not evident until approximately 80 minutes, with final values being $75 \%$ of the initial value. For both rat and human tissue, short-circuit current initially rose during the first 40 (rat) to 60 (human) minutes after mounting the tissue in the chamber. Isc was maintained theron for the remainder of the timecourse. Conversely, $\mathrm{R}$ initially fell during the 40 minute equilibration period in both species. $\mathrm{R}$ in the human tissue then remained stable, with rat jejunal $\mathrm{R}$ showing a small rise towards 120 minutes.

Figure 2 displays the response to $\mathrm{CCh}$ for both rat and human excised intestine in these studies. Rat tissue displayed a $29 \%$ increase in Isc in response to CCh, from 124 to $159 \mu \mathrm{A} . \mathrm{cm}^{-2}(n=15$, $\mathrm{P}<0.05)$. Human intestinal tissue showed a larger response with Isc increasing $50 \%$ following basolateral CCh, from 122 to $183 \mathrm{~A}^{-\mathrm{cm}^{-2}}(n=20, \mathrm{P}<0.001)$.

In addition to real-time electrical indications of tissue viability and integrity, measuring the passive permeability of a paracellular molecule acts as more sensitive control for disrupted tissue integrity. Atenolol was chosen as a paracellular marker [14] amenable to analysis by LC MS/MS. As can be seen in Figure 3, atenolol flux remained linear for the timecourse of the experiments in both rat and human tissue, indicating maintained tissue integrity $\left(\mathrm{R}^{2}=0.984\right.$ and 
BDD-10-0113-R1

0.996, respectively). There was no statistical difference between paracellular atenolol permeability in either species.

\section{Buffer conditions (constant gassing vs pre-saturation)}

The supply of oxygen to excised tissue sections is critical to maintaining viability and integrity once mounted in Ussing Chambers [11]. As transport logistics prevented constant gassing of human tissue in Kreb's bicarbonate ringer (KBR) from the Hospital to the laboratory, rat tissue was initially assessed to determine any impact on viability and integrity with regard to constantly gassed tissue vs pre-saturated buffer. Ice-cold KBR was used in both instances. Verapamil was used as a high permeability marker of transcellular permeability with atenolol used as a paracellular marker. KBR was either continuously perfused with carbogen or pre-saturated before being placed in a sealed, gas impermeable flask. Figure 4 (A) shows that there was no difference between either verapamil or atenolol absorptive permeability when tissue was transported in constantly gassed or pre-saturated, ice-cold KBR buffer. In addition Figures 4 (B), (C) and (D) indicate that electrical parameters were not affected, with PD, Isc and Rt values at time 0 effectively equal in both groups ( $n=3$ separate animals, NS).

\section{Rat jejunum, human jejunum and Caco-2 permeability}

The compounds selected for permeability experiments in rat jejunal tissue spanned a range of physicochemical space and human fraction absorbed values (Table 1). They include compounds subject to passive transcellular and paracellular movement, as well as active transport. The absorptive (mucosal to serosal) apparent permeability (Papp) values generated across the rat and human intestine are displayed in Table 2, alongside the human fraction absorbed values (Fabs), taken from various literature sources. The rank ordering between high-low permeability values in the rat jejunum and high-low human fraction absorbed values display a good agreement. The 


\section{BDD-10-0113-R1}

ordering does not appear to be as closely matched when looking at values generated in Caco-2 monolayers (Table 2).

The permeability of a number of the compounds investigated in rat intestine was also measured in the human jejunum sourced from pancreatoduodenectomy. The permeability values are shown in Table 2, displaying a rank ordering broadly in agreement with that of the rat intestinal tissue. When plotted against the Papp values generated in rat (Figure 5A), there is an excellent linear correlation $\left(\mathrm{R}^{2}=0.86, \mathrm{P}<0.05\right)$. However, the relationship does not follow the line of unity Compounds with Papp values $>20 \mathrm{~cm} / \mathrm{s}\left(\times 10^{-6}\right)$ in the rat intestine show considerably higher values than were measured the human intestine (Figure 5C). If the analysis only includes compounds below this Papp value in the rat, it is apparent that permeability is remarkably similar in both species (Figure 5B)

For compounds known to permeate predominantly via the paracellular route (i.e. atenolol, ranitidine) extremely low Papps are noted in Caco-2 cells, believed to result from the enhanced tight-junctional barrier in these cultured layers in relation to intact intestinal tissue [15]. This results in much poorer correlations when compared directly against the values generated in rat and human tissue.

The Papp values generated in Caco-2 monolayers, rat and human tissue can be related to human fraction absorbed (hFabs) whereby they are plotted on a logarithmic scale against the hFabs values. As can be seen in Figure 6A, there is a sigmoidal relationship $\left(\mathrm{R}^{2}=0.73\right)$ between rat Papp and human Fabs, which mimics the output of research conducted by other groups with an alternative set of probe compounds [16]. The Papp values generated in the human small intestine with a subset of compounds also measured in that rat were plotted against hFabs values to produce the relationship shown in Figure 6B. The sigmoidal regression shows a marginally stronger correlation than was obtained using rat intestinal tissue $\left(\mathrm{R}^{2}=0.80\right)$. With the Caco-2 values, a markedly different curve is observed (Figure 6C), due mainly to the low permeability 


\section{BDD-10-0113-R1}

values measured for the more hydrophilic compounds. The regression analysis indicates a strong correlation $\left(\mathrm{R}^{2}=0.92\right)$ with human Fabs.

In overlaying both human and rat Fabs curves, it can be seen that the relationship between Papp and human fraction absorbed is qualitatively similar for the training set of compounds used in this assay (Figure 6D) 
BDD-10-0113-R1

\section{Discussion}

The use of excised intestinal tissue in modified Ussing chambers has been developed for the study of permeability and absorption potential of NCEs. Previous investigations have defined explicit criteria for determining the viability of this excised tissue and it is recognised that maintained perfusion in situ is critical for maintaining viability ex vivo [11]. The stripping process has previously been shown to have no detrimental impact on excised tissue [4] and was not specifically investigated in this study. The electrical parameters recorded in this study broadly agree with those measured in other laboratories for both rat and human tissue $[4,11,17]$ Active ion transport is maintained in tissue sections from both species, however the PDs do fall over the course of the experiment. Previous studies have shown that at 90 minutes, tissue damage can be observed in morphological assessments [10]. However, in the study by Soderholm et al [9], a drop in PD was noted prior to these signs of structural damage, indicating a reduction in ion transport, rather than a disruption of the tissue morphology. In the present study, chloride-related increases in Isc induced by the addition of CCh demonstrated that despite a fall in PD, the tissue sections remain metabolically active at the end of the incubation period.

Tissue resistance was found to be well maintained over the course of the experiment, although the relevance of this measure as an indicator of the extent of leak in a whole tissue section has been questioned in the past $[11,14]$. Small reductions in tissue integrity may not necessarily be reflected by changes in resistance. As such it is important to include a marker of paracellular permeability to assess leak upon post-experiment analysis. Atenolol, as a suitable molecule for this purpose $[1,14]$ was found to remain constant over the duration of the experiment and not to differ between human and rat tissues. In terms of tissue viability, human intestine excised during pancreatoduodenectomy retains the function of energy (ATP) dependent processes and displays maintained integrity over the course of an Ussing chamber experiment of up to 2 hours. Human tissue removed during pancreatoduodenectomy appears to show a greater degree of electrical 


\section{BDD-10-0113-R1}

stability than rat tissue, with the reduction in potential difference evident later in the experimental timecourse.

The comparable rank ordering profile between rat and human Papp values described in our results has been previously reported for an alternate set of compounds [16] confirming the utility of human tissue from pancreatoduodenectomy in determining intestinal permeability of a range of drug compounds. In directly comparing the relationship between permeability in the rat and human intestine, a bias towards higher permeability values in the rat was evident. It has previously been suggested [2] that cross-species differences in the permeability of rapidly absorbed compounds are likely to result from differences in unstirred water layer (UWL) thickness, given the evidence that lipophilic compounds are influenced to a greater degree by the thickness of UWL [18]. This could therefore be responsible for the apparent bias towards higher rat jejunal permeability shown by the compounds with a rat Papp of $>20 \mathrm{~cm} / \mathrm{s}\left(\times 10^{-6}\right)$. Similar results have been reported previously, whereby non-linearity between rat Papp and Peff values were evident for higher permeability compounds, again suggested by the authors to be the result of difference in UWL [16]. In terms of permeability measurements across Caco- 2 cells, it is recognised that limits are imposed by the presence of an UWL that is considerably thicker than is found in vivo [19-20]. In addition, the expression levels of certain active transport proteins may well differ between the cell system and intact intestinal tissue [8], therefore impacting on the permeability of substrates. As differences in UWL thickness exist, without active stirring of the cellular monolayers it is likely that the permeability of lipophilic compounds will be limited in this system. The reduction of UWL thickness by gas-lift in the Ussing chamber has been previously noted [20] and may indicate that a narrower UWL exists, allowing for higher permeability of rapidly absorbed compounds across intact tissue in this system when compared with the 'unstirred' Caco-2 monolayers. The UWL has been suggested to have little impact for 
BDD-10-0113-R1

slowly absorbed (hydrophilic) drugs where permeation across the cell membrane (or through the paracellular route) is likely to be the rate limiting step [21].

When directly comparing the permeability of rat and human jejunal tissue with the reported hFab values, the relationships are remarkably alike. This could indicate that rat jejunum is capable of predicting drug permeability across human jejunum and by extrapolation, producing a tentative prediction of human Fabs. However, there are caveats to be aware of when making these assessments. Differences in active transport or metabolism between the two species could result in significant differences in Fabs, which are unlikely to be predicted using a static regression curve relating Papp and hFabs, as shown here.

In comparing these results to previously published data, both in terms of tissue viability and permeability relationships, it is apparent that the system developed in our laboratory produces analogous results $[11,16]$. It is therefore apparent that these relationships hold true for a diverse range of compounds in terms of both physicochemical properties and mechanisms of permeability (passive versus active).

\section{Conclusions}

Surplus human small intestine removed during pancreatoduodenectomy has been found to remain viable and intact for use in Ussing Chamber investigation, displaying maintained ion transport and electrical resistance. Over a 2 hour timecourse in the chambers, both rat and human tissue sections retain ATP-hydrolysis and paracellular leak is not compromised, as determined by atenolol flux. Permeability measures across human tissue are comparable with data generated in excised rat intestinal sections, with excellent agreement in terms of rank-ordering. Caco-2 monolayers do not display a comparable permeability profile to the excised intestinal tissue, which may be related to differences in UWL thickness, paracellular permeability or transporter expression levels. In relating permeability to known human fraction absorbed values, rat and 


\section{BDD-10-0113-R1}

human excised tissue give qualitatively similar correlations. These results are analogous to previously published data generated using an alternative compound test set and tissue sourced from different surgeries. Human jejunal tissue excised during pancreatoduodenectomy is therefore useful in assessing compound permeability and absorption potential in the drug discovery setting. 


\title{
BDD-10-0113-R1
}

\begin{abstract}
Acknowledgments
The authors are extremely grateful to Tracey Randall, Jacqui Aitchison and Huw Bowen for all their assistance in gaining ethical approval for accessing pancreatoduodenectomy tissue, as well as in the setting up of study agreements and subsequent monitoring of the study. Stephanie Church and Joanne Shaw (CVGI DMPK, AstraZeneca, UK) conducted the Caco-2 studies described within and the authors thank them for providing this data. Iain Haslam would like to thank Professor Nick Simmons (Epithelial Research Group, Newcastle University, UK) for his useful discussions and insightful comments when reviewing this manuscript.
\end{abstract}


BDD-10-0113-R1

\section{References}

[1] Artursson, P., Karlsson, J. (1991). Correlation between oral drug absorption in humans and apparent drug permeability coefficients in human intestinal epithelial (caco-2) cells. Biochem. Biophys. Res. Commun. 175, 880-5.

[2] Jezyk, N., Rubas, W. \& Grass, G.M. (1992). Permeability characteristics of various intestinal regions of rabbit, dog, and monkey. Pharm. Res. 9, 1580-6.

[3] Ungell, A.L., Nylander, S., Bergstrand, S., Sjoberg, A. \& Lennernas, H. (1998). Membrane transport of drugs in different regions of the intestinal tract of the rat. J. Pharm. Sci. 87, 360-6, $10.1021 /$ js970218s.

[4] Nejdfors, P., Ekelund, M., Jeppsson, B. \& Westrom, B.R. (2000). Mucosal in vitro permeability in the intestinal tract of the pig, the rat, and man: Species- and region-related differences. Scand. J. Gastroenterol. 35, 501-7.

[5] Bajka, B.H., Gillespie, C.M., Steeb, C.B., Read, L.C. \& Howarth, G.S. (2003). Applicability of the ussing chamber technique to permeability determinations in functionally distinct regions of the gastrointestinal tract in the rat. Scand. J. Gastroenterol. 38, 732-41.

[6] Lucas, M.L., Blair, J.A., Cooper, B. \& Matty, A.J. (1975). Further investigations with pH microelectrodes into the jejunal microclimate in rat and man. Gut. 16, 844.

[7] van de Kerkhof, E.G., Ungell, A.L., Sjoberg, A.K., de Jager, M.H., Hilgendorf, C., de Graaf, I.A. \& Groothuis, G.M. (2006). Innovative methods to study human intestinal drug metabolism in vitro: Precision-cut slices compared with ussing chamber preparations. Drug Metab. Dispos. 34, 1893-902, 10.1124/dmd.106.011148.

[8] Hilgendorf, C., Ahlin, G., Seithel, A., Artursson, P., Ungell, A.L. \& Karlsson, J. (2007). Expression of thirty-six drug transporter genes in human intestine, liver, kidney, and organotypic cell lines. Drug Metab. Dispos. 35, 1333-40, 10.1124/dmd.107.014902.

[9] Hidalgo, M. (2010). Pancreatic Cancer. N. Engl. J. Med. 362, 1605-17

[10] Soderholm, J.D., Hedman, L., Artursson, P., Franzen, L., Larsson, J., Pantzar, N., Permert, J. \& Olaison, G. (1998). Integrity and metabolism of human ileal mucosa in vitro in the ussing chamber. Acta Physiol. Scand. 162, 47-56.

[11] Polentarutti, B.I., Peterson, A.L., Sjoberg, A.K., Anderberg, E.K., Utter, L.M. \& Ungell, A.L. (1999). Evaluation of viability of excised rat intestinal segments in the ussing chamber: Investigation of morphology, electrical parameters, and permeability characteristics. Pharm. Res. 16, 446-54.

[12] Dharmsathaphorn, K., Pandol, S.J. (1986). Mechanism of chloride secretion induced by carbachol in a colonic epithelial cell line. J. Clin. Invest. 77, 348-54, 10.1172/JCI112311.

[13] McEwan, G.T., Hirst, B.H. \& Simmons, N.L. (1994). Carbachol stimulates cl- secretion via activation of two distinct apical cl- pathways in cultured human T84 intestinal epithelial monolayers. Biochim. Biophys. Acta. 1220, 241-7. 
[14] Collett, A., Walker, D., Sims, E., He, Y.L., Speers, P., Ayrton, J., Rowland, M. \& Warhurst, G. (1997). Influence of morphometric factors on quantitation of paracellular permeability of intestinal epithelia in vitro. Pharm. Res. 14, 767-73.

[15] Artursson, P., Palm, K. \& Luthman, K. (2001). Caco-2 monolayers in experimental and theoretical predictions of drug transport. Adv. Drug Deliv. Rev. 46, 27-43.

[16] Lennernas, H. (1997). Human jejunal effective permeability and its correlation with preclinical drug absorption models. J. Pharm. Pharmacol. 49, 627-38.

[17] Corbett, C.L., Isaacs, P.E., Riley, A.K. \& Turnberg, L.A. (1977). Human intestinal ion transport in vitro. Gut. 18, 136-40.

[18] Winne, D. (1978). Dependence of intestinal absorption in vivo on the unstirred layer. Naunyn Schmiedebergs Arch. Pharmacol. 304, 175-81.

[19] Hidalgo, I.J., Hillgren, K.M., Grass, G.M. \& Borchardt, R.T. (1991). Characterization of the unstirred water layer in caco-2 cell monolayers using a novel diffusion apparatus. Pharm. Res. 8, 222-7.

[20] Karlsson, J., Artursson, P. (1992). A new diffusion chamber system for the determination of drug permeability coefficients across the human intestinal epithelium that are independent of the unstirred water layer. Biochim. Biophys. Acta. 1111, 204-10.

[21] Fagerholm, U., Lennernas, H. (1995). Experimental estimation of the effective unstirred water layer thickness in the human jejunum, and its importance in oral drug absorption. Eur $J$ Pharm Sci. 3, 247.

[22] McGinnity, D.F., Collington, J., Austin, R.P. \& Riley, R.J. (2007). Evaluation of human pharmacokinetics, therapeutic dose and exposure predictions using marketed oral drugs. Curr. Drug Metab. 8, 463-79.

[23] Zhao, Y.H., Le, J., Abraham, M.H., Hersey, A., Eddershaw, P.J., Luscombe, C.N., Butina, D., Beck, G., Sherborne, B., Cooper, I. \& Platts, J.A. (2001). Evaluation of human intestinal absorption data and subsequent derivation of a quantitative structure-activity relationship (QSAR) with the abraham descriptors. J. Pharm. Sci. 90, 749-84.

[24] Palm, K., Stenberg, P., Luthman, K. \& Artursson, P. (1997). Polar molecular surface properties predict the intestinal absorption of drugs in humans. Pharm. Res. 14, 568-71.

[25] Zhu, C., Jiang, L., Chen, T.M. \& Hwang, K.K. (2002). A comparative study of artificial membrane permeability assay for high throughput profiling of drug absorption potential. Eur. J. Med. Chem. 37, 399-407.

[26] Sugano, K., Hamada, H., Machida, M., Ushio, H., Saitoh, K. \& Terada, K. (2001). Optimized conditions of bio-mimetic artificial membrane permeation assay. Int. J. Pharm. 228, 181-8.

[27] Kansy, M., Senner, F. \& Gubernator, K. (1998). Physicochemical high throughput screening: Parallel artificial membrane permeation assay in the description of passive absorption processes. J. Med. Chem. 41, 1007-10, 10.1021/jm970530e. 


\section{BDD-10-0113-R1}

[28] Chiou, W.L., Barve, A. (1998). Linear correlation of the fraction of oral dose absorbed of 64 drugs between humans and rats. Pharm. Res. 15, 1792-5.

[29] Terao, T., Hisanaga, E., Sai, Y., Tamai, I., Tsuji, A. (1996). Active secretion of drugs from the small intestinal epithelium in rats by P-glycoprotein functioning as an absorption barrier. $J$. Pharm. Pharmacol. 48, 1083-9

[30] Darnell, M., Karlsson, J.E., Owen, A., Hidalgo, I.J., Li, J., Zhang, W., Andersson, T.B. (2010). Investigation of the involvement of P-glycoprotein and multidrug resistance-associated protein 2 in the efflux of ximelagatran and its metabolites by using short hairpin RNA knockdown in Caco-2 cells. Drug. Metab. Dispos. 38, 491-7

[31] Yokooji, T., Yumoto, R., Nagai, J., Takano, M., Yokooji, T., Murakami, T. (2007). Role of intestinal efflux transporters in the intestinal absorption of methotrexate in rats. J. Pharm.

Pharmacol. 59, 1263-70 
BDD-10-0113-R1

\section{Figure 1.}

Changes in electrical parameters, $(\mathrm{A})$ potential difference $(\mathrm{mV}),(\mathrm{B})$ short-circuit current $\left(\mu \mathrm{A} . \mathrm{cm}^{-}\right.$

${ }^{2}$ ) and $(\mathrm{C})$ resistance $\left(\Omega . \mathrm{cm}^{2}\right)$, in rat (closed circles) and human (open circles) jejunum over a 160 minute period in Ussing Chambers.

\section{Figure 2.}

Changes in short-circuit current $\left(\mu \mathrm{A} . \mathrm{cm}^{-2}\right)$ across rat (closed circles) and human (open circles) jejunum, in response to $100 \mu \mathrm{M}$ basolateral carbachol stimulation following 160 minutes in Ussing Chambers.

\section{Figure 3.}

Flux of atenolol $(100 \mu \mathrm{M})$ across rat and human jejunum, mounted in Ussing chambers for 120 minutes. Linear regression indicates $\mathrm{R}^{2}$ values of 0.99 and 0.98 for atenolol flux across human and rat intestine, respectively.

\section{Figure 4.}

(A) Verapamil and atenolol permeability across rat jejunum mounted in Ussing chambers following transport in constantly perfused KBR (open bars) and pre-saturated KBR (closed bars). Comparison of electrical parameters (B) PD, (C) Isc and (D) resistance for across rat jejunum mounted in Ussing chambers following transport in constantly perfused KBR (open bars) and pre-saturated KBR (closed bars).

\section{Figure 5.}

(A) Correlation between rat and human jejunum apparent permeability (Papp, $\mathrm{cm} . \mathrm{s}^{-1} \times 10^{-6}$ ), measured in vitro using Ussing chambers. Correlations are shown for compounds displaying a 


\section{BDD-10-0113-R1}

Papp of $<20 \mathrm{~cm} \cdot \mathrm{s}^{-1} \times 10^{-6}$ in rat jejunum (B) and $>20 \mathrm{~cm} \cdot \mathrm{s}^{-1} \times 10^{-6}$ in rat jejunum (C). Data are mean values generated using tissue from at least 3 separate rats or human donors.

\section{Figure 6.}

Relationship between drug permeability (Papp) measured in (A) rat jejunum, (B) human jejunum and (C) Caco-2 cell monolayers and the human fraction absorbed values as reported in the literature. An overlay of the 3 regression curves is displayed in (D). Papp values are the mean of measurements in tissue from at least 3 separate rats or human donors. 
BDD-10-0113-R1

Table 1. Physicochemical properties and fraction absorbed (Fabs) values for drug compound test set.

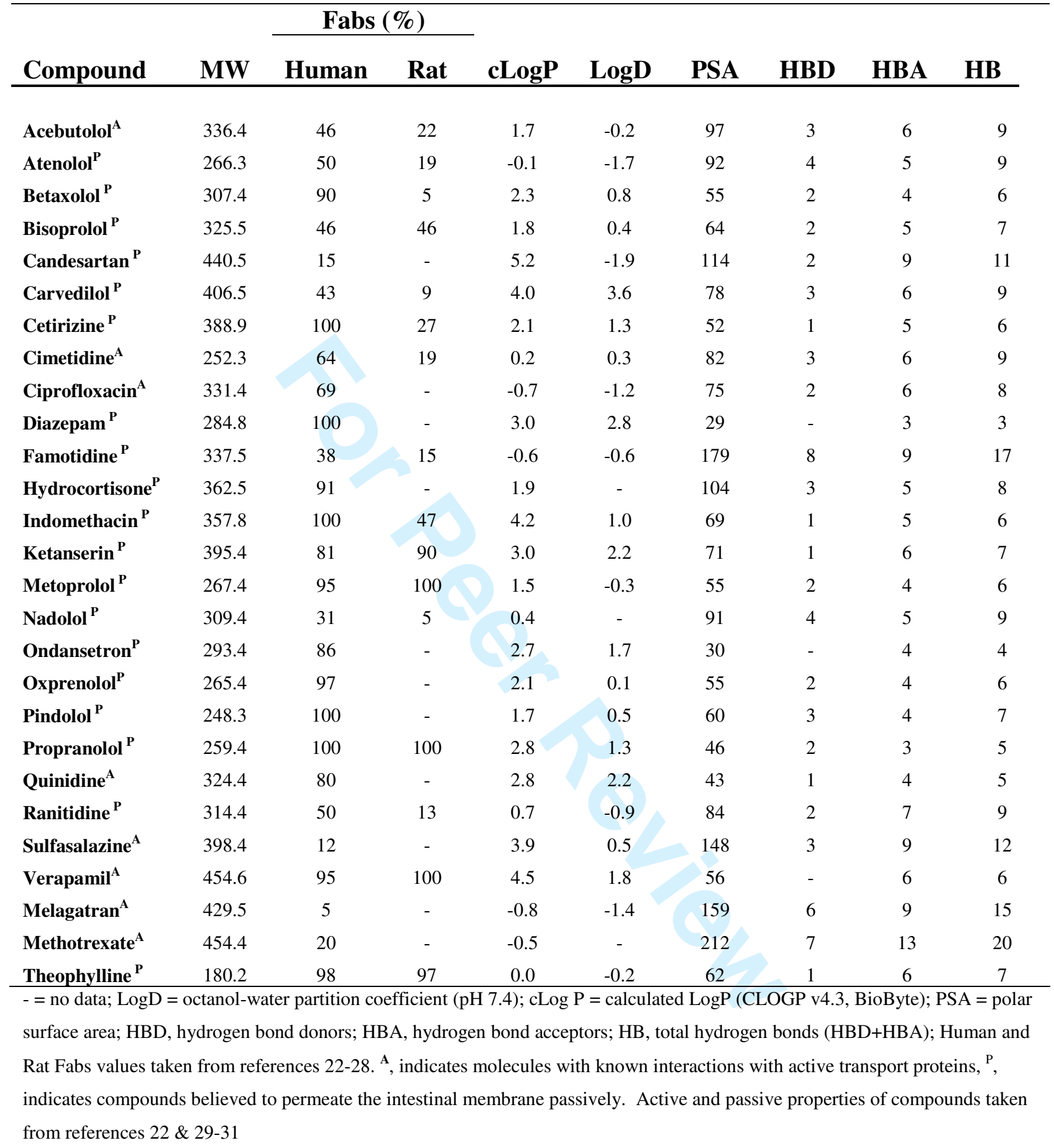


BDD-10-0113-R1

Table 2. Apparent permeability (Papp, $P a-b$ ) values across Caco-2 cell monolayers, rat jejunum and human jejunum.

$\begin{array}{ccc}\text { Rat } & \text { Human } & \text { Caco-2 } \\ \text { jejunum } & \text { jejunum }\end{array} \quad$ Lanter

\section{Compound}

$$
\text { Papp }\left(\mathrm{cm} / \mathrm{s} \mathrm{x10}^{-6}\right)
$$

Rank Order (rat/human

Fabs Papp)

\begin{tabular}{lccccc} 
Diazepam & 127.9 & 89.0 & 27.0 & $1 / 1$ & 100 \\
Propranolol & 89.0 & 37.4 & 15.9 & $2 / 2$ & 100 \\
Verapamil & 88.6 & - & 15.1 & - & 95 \\
Ketanserin & 48.2 & - & 36.6 & - & 81 \\
Pindolol & 41.9 & 35.8 & 29.4 & $3 / 3$ & 100 \\
Quinidine & 41.0 & - & 23.2 & - & 80 \\
Cetirizine & 37.9 & 19.1 & 15.9 & $4 / 4$ & 100 \\
Indomethacin & 33.2 & - & 31.1 & - & 100 \\
Ciprofloxacin & 27.0 & 15.7 & 2.9 & $5 / 6$ & 69 \\
Ondansetron & 26.1 & - & 22.3 & - & 86 \\
Hydrocortisone & 25.5 & - & - & - & 91 \\
Oxprenolol & 23.3 & - & 28.4 & - & 97 \\
Betaxolol & 21.5 & - & 28.1 & - & 90 \\
Theophylline & 17.3 & - & 13.7 & - & 98 \\
Metoprolol & 13.2 & 17.8 & 27.9 & $6 / 5$ & 95 \\
Atenolol & 12.1 & - & 0.6 & - & 50 \\
Acebutolol & 10.8 & 11.0 & 1.6 & $7 / 7$ & 46 \\
Bisoprolol & 10.4 & - & 17.3 & - & 46 \\
Methotrexate & 10.4 & - & 0.2 & - & 20 \\
Cimetidine & 9.5 & 10.7 & 0.7 & $8 / 8$ & 64 \\
Nadolol & 9.5 & - & 0.4 & - & 31 \\
Famotidine & 6.5 & - & 0.4 & - & 38 \\
Melagatran & 5.5 & - & 0.1 & - & 5 \\
Candesartan & 4.7 & 3.6 & 0.3 & $9 / 10$ & 15 \\
Ranitidine & 4.0 & 5.5 & 0.6 & $10 / 9$ & 50 \\
Carvedilol & 3.7 & 2.6 & - & $11 / 11$ & 43 \\
Sulfasalazine & 0.7 & 0.9 & 0.3 & $12 / 12$ & 12 \\
\hline & -5 & -3 & 56 & \\
\hline
\end{tabular}

- = no data; the rank ordering between rat and human Papp values is also displayed; Human Fabs values taken from references 22-28. 
Figure 1 lain Haslam

A

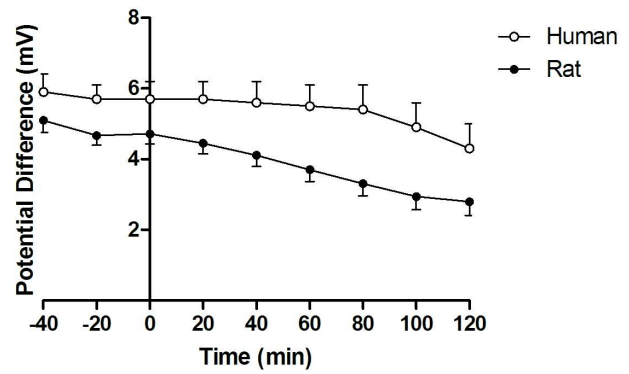

B

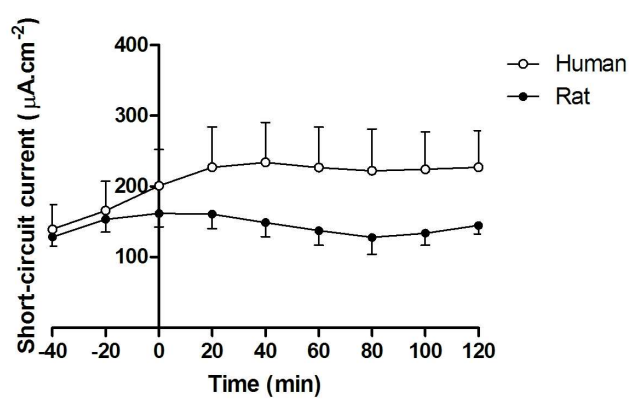

C

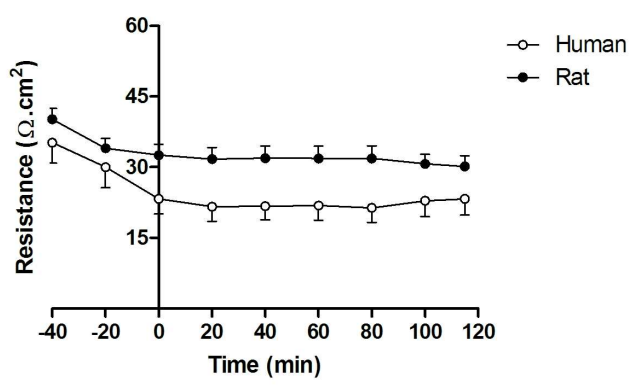




\section{Figure 2 lain Haslam}

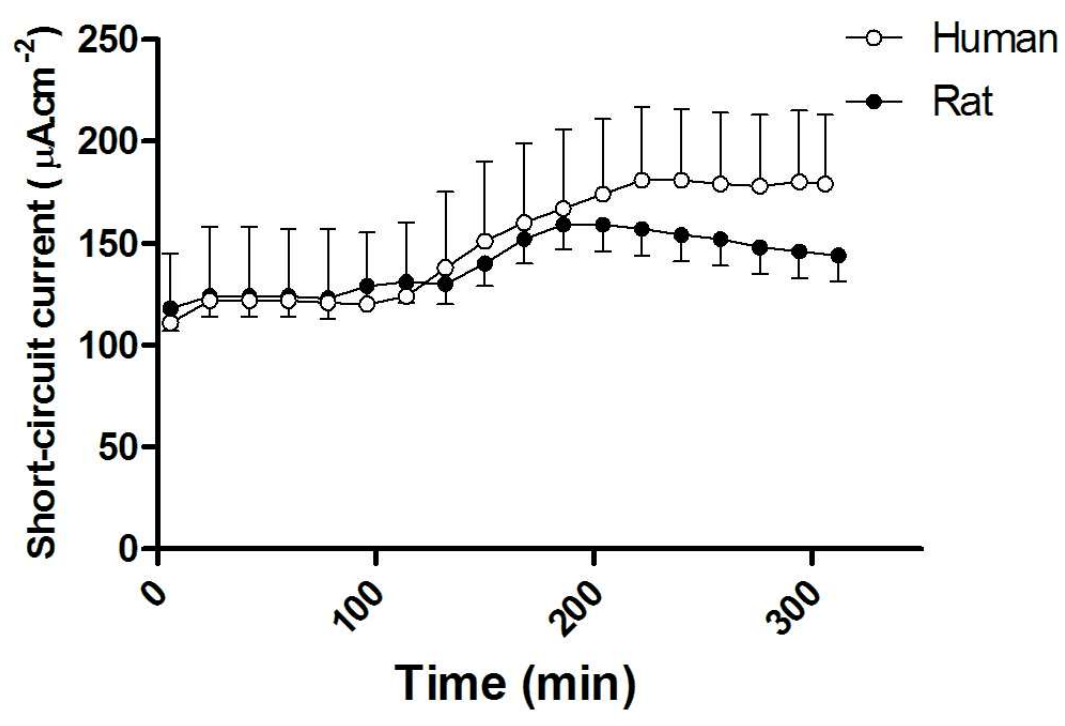

\footnotetext{
Changes in short-circuit current $\left(\mu \mathrm{A} . \mathrm{cm}^{-2}\right)$ across rat (closed circles) and human (open circles) jejunum, in response to $100 \mu \mathrm{M}$ basolateral carbachol stimulation following 160 minutes in Ussing Chambers.

$103 \times 117 \mathrm{~mm}(300 \times 300 \mathrm{DPI})$
} 
Figure 3 Iain Haslam

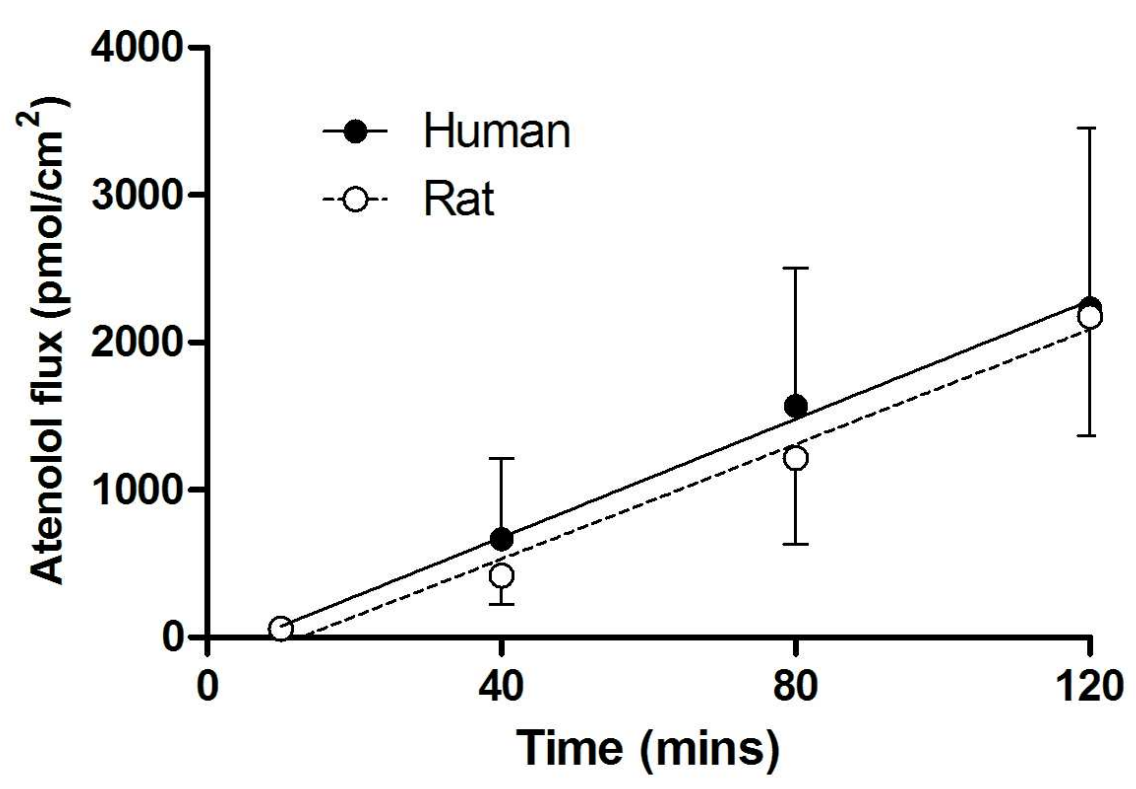

Flux of atenolol $(100 \mu \mathrm{M})$ across rat and human jejunum, mounted in Ussing chambers for 120 minutes. Linear regression indicates $\mathrm{R}^{2}$ values of 0.99 and 0.98 for atenolol flux across human and rat intestine, respectively. $112 \times 124 \mathrm{~mm}(300 \times 300 \mathrm{DPI})$ 


\section{Figure 4} lain Haslam

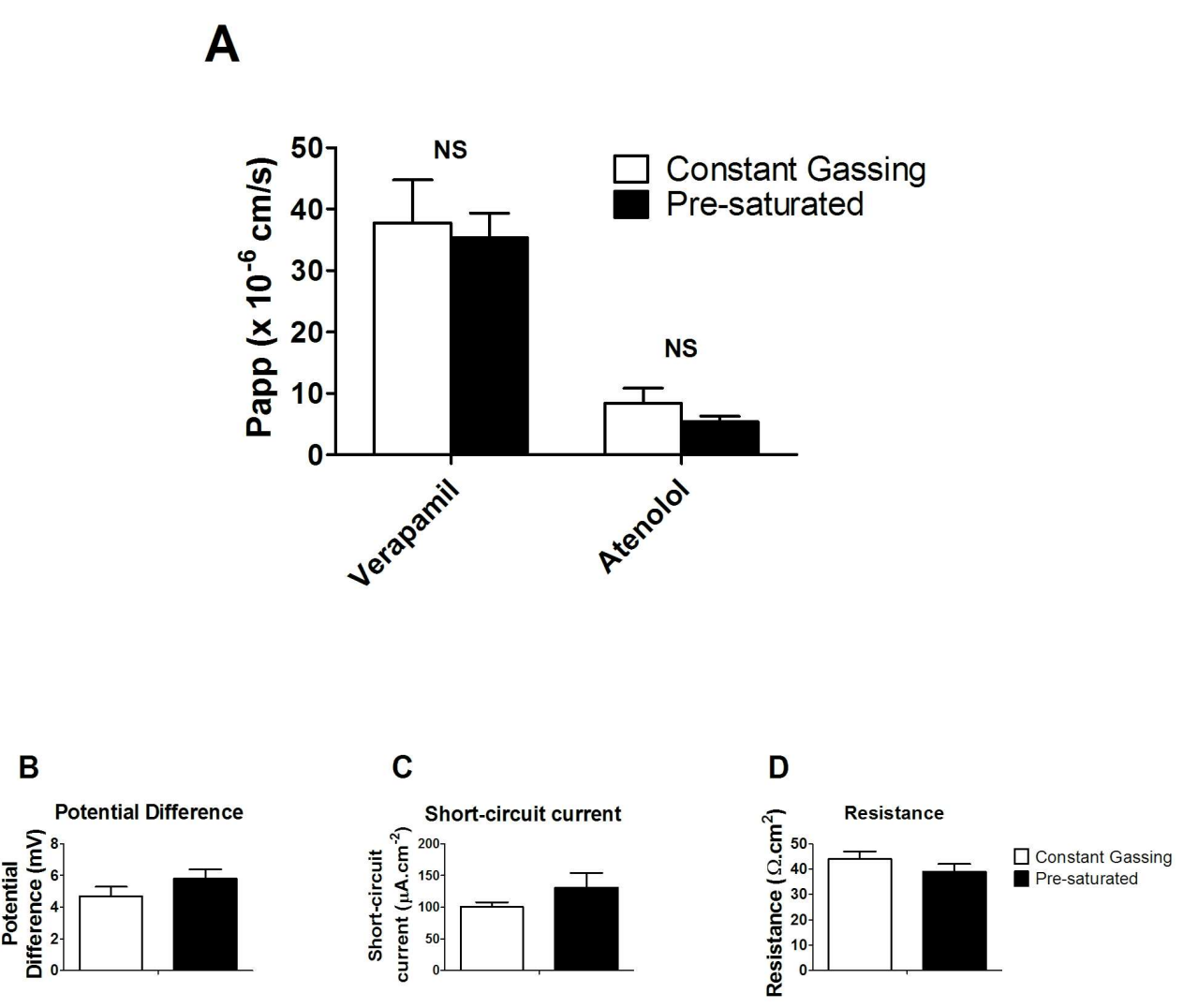

(A) Verapamil and atenolol permeability across rat jejunum mounted in Ussing chambers following transport in constantly perfused KBR (open bars) and pre-saturated KBR (closed bars). Comparison of electrical parameters (B) PD, (C) Isc and (D) resistance for across rat jejunum mounted in Ussing chambers following transport in constantly perfused KBR (open bars) and pre-saturated KBR (closed bars).

$169 \times 187 \mathrm{~mm}(300 \times 300 \mathrm{DPI})$ 
Figure 5 lain Haslam

(A) Correlation between rat and human jejunum apparent permeability (Papp, $\mathrm{cm} . \mathrm{s}^{-1} \times 10^{-6}$ ), measured in vitro using Ussing chambers. Correlations are shown for compounds displaying a Papp of $<20 \mathrm{~cm} \cdot \mathrm{s}^{-1} \times 10^{-6}$ in rat jejunum (B) and $>20 \mathrm{~cm} \cdot \mathrm{s}^{-1} \times 10^{-6}$ in rat jejunum (C). Data are mean values generated using tissue from at least 3 separate rats or human donors.

\section{$172 \times 268 \mathrm{~mm}(300 \times 300 \mathrm{DPI})$}


A

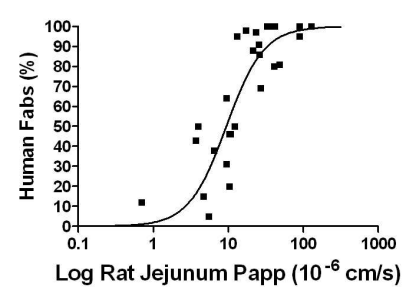

B

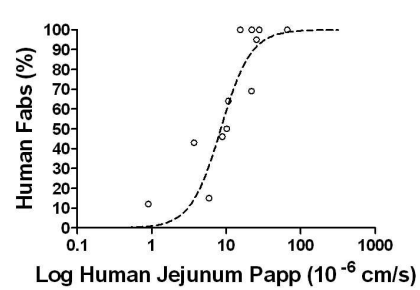

C

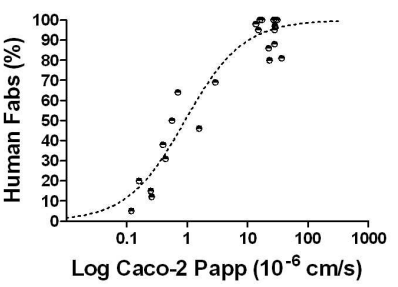

16

17

18

19

20

21

22

23

24

25

26

27

28

29

30

31

32

33

34

35

36

37

38

39

40

41

42

43

44

45

46

47

48

49

50

51

52

53

54

55

56

57

58

59

60

Relationship between drug permeability (Papp) measured in (A) rat jejunum, (B) human jejunum and (C) Caco-2 cell monolayers and the human fraction absorbed values as reported in the literature. An overlay of the 3 regression curves is displayed in (D). Papp values are the mean of measurements in tissue from at least 3 separate rats or human donors.

$187 \times 181 \mathrm{~mm}(300 \times 300 \mathrm{DPI})$ 


\section{BDD-10-0113-R1}

Pancreatoduodenectomy as a source of human small intestine for Ussing Chamber Investigations and comparative studies with rat tissue

Iain S Haslam', Derek A O’Reilly ${ }^{2,3}$, David J Sherlock ${ }^{2}$, Ambareen Kauser², Chris Womack ${ }^{4}$, Tanya Coleman ${ }^{1}$

${ }^{1}$ Drug Metabolism and Pharmacokinetics, AstraZeneca Research \& Development, Alderley Park, Macclesfield, Cheshire, SK10 4TG

${ }^{2}$ Department of Surgery, North Manchester General Hospital, Pennine Acute Hospitals Trust, Delaunays Road, Manchester, M8 5RB

${ }^{3}$ Cancer Studies Research Group, The University of Manchester, Manchester Academic Health Science Centre, Manchester, UK.

${ }^{4}$ CDXT, AstraZeneca, Alderley Park, Macclesfield, Cheshire, SK10 4TG 


\section{BDD-10-0113-R1}

Running Title: Ussing Chamber investigations using excised human intestine

\section{Corresponding Author:}

Dr Iain Haslam

Drug Metabolism and Pharmacokinetics

AstraZeneca Research and Development

Alderley Park

Macclesfield

SK10 4TG

Phone: 0161233057

iain.haslam@astrazeneca.com 
BDD-10-0113-R1

\begin{abstract}
.
A clear understanding of oral drug absorption is an important aspect of the drug development process. The permeability of drug compounds across intact sections of small intestine from numerous species, including man, has often been investigated using modified Ussing Chambers. The maintenance of viable, intact tissue is critical to the success of this technique. This study therefore aimed to assess the viability and integrity of tissue from patients undergoing pancreatoduodenectomy, for use in cross-species Ussing chamber studies. Electrical parameters (potential difference; $\mathrm{mV}$, short-circuit current; $\mu \mathrm{A} . \mathrm{cm}^{-2}$ and resistance; $\Omega / \mathrm{cm}^{2}$ ) were monitored over the duration of each experiment, as was the permeability of the paracellular marker atenolol. The permeability values (Papp; $\mathrm{cm} / \mathrm{s} \times 10^{-6}$ ) for a training-set of compounds, displaying a broad range of physicochemical properties and known human fraction absorbed values, were determined in both rat and human jejunum, as well as Caco-2 cell monolayers. Results indicate that human jejunum sourced from pancreatoduodenectomy remained viable and intact for the duration of experiments. Permeability values generated in rat and human jejunum correlate well $\left(\mathrm{R}^{2}=0.86\right)$, however the relationship between permeability in human tissue and Caco-2 cells was comparatively weak $\left(\mathrm{R}^{2}=0.58\right)$. Relating permeability to known human fraction absorbed (hFabs) values results in a remarkably similar relationship to both rat and human jejunum Papp values.

It can be concluded that human jejunum sourced from pancreatoduodenectomy is a suitable source of tissue for Ussing chamber permeability investigations. The relationship between permeability and hFabs is comparable with results reported using alternative test compounds.
\end{abstract}

Keywords: Ussing Chamber, absorption, drug development, pancreatoduodenectomy 


\section{BDD-10-0113-R1}

\section{Introduction}

The measurement and prediction of oral drug absorption in the early drug discovery process is a complex task fraught with interpretation difficulties resulting from species-specific interactions and the limited physiological relevance of certain in vitro tools. Cell based assays such as Caco-2 are commonly used as an up-front screening tool for indicating the permeability of candidate compounds and by extrapolation, the "absorption potential". These cells are also often used for mechanistic studies in order to identify potential interactions with efflux transporters that could limit intestinal absorption or prevent access to the site of action [1]. Preclinical pharmacokinetic (PK) studies performed during lead optimisation give the first in vivo measure of absorption and can highlight potential limitations in bioavailability caused by intestinal processes. However, the use of rat, dog and mouse species at this stage may give contrasting data, leading to significant difficulty in accurately predicting the likely situation in man.

Modified Ussing chambers have been used for some time to study the permeability and absorption potential of New Chemical Entities (NCEs) across excised sections of intact intestinal tissue. In this way, species and region specific difference in permeability, transport and metabolic capability have been identified [2-5]. The significant advantage offered by Ussing chamber studies over cultured cell lines is the maintenance of the complex cellular heterogeneity and morphology of the mammalian intestine (including crypt-villus structures), which is not entirely mimicked by the relatively homogeneous cellular monolayer of a Caco-2 system. The presence of an extended plethora of transport proteins and drug metabolising enzymes (DMEs) as well as an intact acid microclimate mucous layer adjacent to the villus tip enterocytes, results in an experimental system that gives a more complete picture regarding processes that may impact on absorption [6-8].

Pancreatoduodenectomy (Whipple's operation) was identified as a potential source of human tissue for Ussing chamber studies. Pancreatoduodenectomy is a first-line treatment for removal of tumours located in the head of the pancreas and involves the removal of the head of the 
BDD-10-0113-R1

pancreas, duodenum, gall bladder and bile duct along with a short section of jejunum [9]. The jejunum is resected to facilitate surgical reconstruction, not for therapeutic purposes and is therefore redundant for the purposes of pathological examination.

Of critical importance when using ex vivo intestinal sections in Ussing chamber investigations, is the maintenance of tissue integrity and viability. Previous studies have identified certain parameters and set limits for monitoring the health of tissue mounted in the chambers, ensuring accuracy and consistency of the results generated [10-11].

In order to confirm the utility of human tissue sourced from pancreatoduodenectomy, a key aim was therefore to assess tissue integrity following excision and transport to our laboratory. In addition, to allow cross-species comparisons and absorption predictions, the permeability of a number of compounds was assessed using Caco-2 cells and excised rat and human jejunum (from pancreatoduodenectomy). 


\title{
BDD-10-0113-R1
}

\section{Materials \& Methods}

\begin{abstract}
Animals
Male Han Wistar rats (Harlan, UK), aged approximately 100 days and weighing 250-400 g were used in the experiments. They were kept at a room temperature of $18{ }^{\circ} \mathrm{C}$ to $22{ }^{\circ} \mathrm{C}$ and a relative humidity of $30 \%$ to $60 \%$ under a 12-hour light/dark cycle and had free access to food and tap water. The rats were allowed to acclimatise for at least one week after arrival at AstraZeneca R\&D Alderley Park.

In order to retain viability of the intestine during surgical excision blood perfusion was maintained under isofluorane (2 L/min, $5 \%$ ) anaesthesia. After abdominal incisions were made, intestinal lumens were occluded by thin cotton thread proximal to the sections of tissue taken from duodenum, jejunum, ileum and colon. The animals were then sacrificed by heart puncture under maintained anaesthesia.
\end{abstract}

A small incision was made distal to the position of the thread to allow $2 \times 20 \mathrm{ml}$ washes of icecold Kreb's bicarbonate Ringer (KBR) solution (pH 7.4) (108.0 mM NaCl, $4.7 \mathrm{mM} \mathrm{KCl}, 0.6 \mathrm{mM}$ $\mathrm{Na}_{2} \mathrm{HPO}_{4} / \mathrm{KH}_{2} \mathrm{PO}_{4}, 16 \mathrm{mM} \mathrm{NaHCO}{ }_{3}, 1.2 \mathrm{mM} \mathrm{MgSO}$, $1.2 \mathrm{mM} \mathrm{CaCl}_{2}, 4.9 \mathrm{mM}$ Na-Pyruvate, 5.4 $\mathrm{mM}$ Fumarate, $4.9 \mathrm{mM}$ L-Glutamate, $11.5 \mathrm{mM}$ Glucose) to remove chyme and faecal matter. The segments were placed in a chamber containing ice-cold KBR perfused with carbogen $(95 \%$ $\mathrm{O}_{2}, 5 \% \mathrm{CO}_{2}$ ) for 30 minutes.

\section{Human small intestine}

Ethical approval was granted (IRAS reference: 09/H1006/2) and tissue samples surplus to the requirements of histopathological assessment were collected from 6 individual donors, in agreement with Surgeons at North Manchester General Hospital. Human tissue samples were collected from 6 male patients, median age 59 (range, 38-68). The specimens were obtained from patients undergoing pancreatoduodenectomy to remove tumours of the head of the pancreas. None of the patients had previously undergone radio- or chemotherapy prior to surgery. 
BDD-10-0113-R1

Perfusion of the intestine was maintained until the moment of excision. Approximately $10 \mathrm{~cm}$ of small intestine was removed and immediately placed in ice-cold KBR, pre-saturated with carbogen. Staples were removed from either end of the resected tissue to allow bathing of the mucosal surface. The tissue was then transported to the laboratories at AstraZeneca. Mean time period between excision of intestinal tissue and transport to our laboratories was $88 \pm 19$ minutes.

\section{Ussing Chamber permeability experiments}

Segments of intestine, avoiding Peyer's patches, were carefully opened along the mesenteric border and pinned onto the silicon base (90\% DC Sylgard 184-base + $10 \%$ DC Sylgard 184-catalyst) of a specially designed preparation chamber containing chilled $\left(10{ }^{\circ} \mathrm{C}\right)$ KBR gassed with carbogen. The serosal layer of the rat jejunum and musculo-serosal layers of human jejunal sections were dissected off with the aid a stereo microscope (Wild M8) and a light source (Schott KL 1500).

Intestinal segments were mounted as flat sheets in a modified Ussing chamber (Harvard Navicyte). The exposed tissue surface area was $0.64 \mathrm{~cm}^{2}$ for rat tissue and $1.78 \mathrm{~cm}^{2}$ for human sections. A 4 electrode system was used for recording electrical parameters. This consisted of 2 $\mathrm{x} \mathrm{Ag} / \mathrm{AgCl}$ electrodes for potential difference (PD) measurement and $2 \mathrm{x} \mathrm{Ag} / \mathrm{AgCl}$ electrodes for current passage. Asymmetry in the PD sensing electrodes was zeroed prior to tissue mounting. Correction for the series fluid resistance was also made in assembled chambers prior to tissue mounting. A $30-40$ minute equilibration period at $37^{\circ} \mathrm{C}$ was allowed prior to the addition of test compounds.

To initiate experiments, the KBR in "donor" or "receiver" wells was replaced with $5 \mathrm{ml}$ of KBR containing the test compounds $(30 \mu \mathrm{M})$ or KBR alone. Samples were removed at 30 minute intervals up to 120 minutes, for analysis by HPLC MS/MS. Fluxes were expressed as nmol. $\mathrm{cm}^{-2} . \mathrm{hr}^{-1}$ or as apparent permeability coefficients $\left(\mathrm{P}_{\mathrm{app}} ; \mathrm{P}_{\mathrm{a}-\mathrm{b}} \& \mathrm{P}_{\mathrm{b}-\mathrm{a}}\right)$ and were calculated as reported previously [10]. $\mathrm{P}_{\mathrm{a}, \mathrm{b}}$ or app is expressed in $\mathrm{cm} / \mathrm{s}$. 


\section{BDD-10-0113-R1}

As a further measure of tissue viability at the end of the experimental period and to confirm the activity of ATP-driven (energy-dependent) processes, $100 \mu \mathrm{M}$ carbachol (CCh) was added to the basolateral chamber. As has previously been established [12-13] CCh elicits an increase in Isc by stimulating chloride secretion upon binding to muscarinic acetylcholine receptors. By measuring an increase in ATP driven, CCh-stimulated chloride secretion, tissue sections can be said to have remained energically active (ATP production and hydrolysis maintained).

\section{Cell Culture}

All cell culture was performed in a class II laminar flow hood (MBSC) under aseptic conditions. Caco-2 cells were maintained in high-glucose (4500 $\mathrm{mg} \mathrm{L}^{-1} \mathrm{D}$-glucose) Dulbecco's Modified Eagle's Medium (DMEM) supplemented with foetal calf serum (10\% v/v), L-glutamine (1 mM), non-essential amino acids $(1 \% \mathrm{v} / \mathrm{v})$ and the antibiotic gentamicin $\left(30 \mu \mathrm{g} \mathrm{ml}^{-1}\right)$. Cells were maintained at $37{ }^{\circ} \mathrm{C}$ in a humidified incubator with $5 \% \mathrm{CO}_{2}$ in air. Cells were seeded onto 96well culture inserts (Transwell 3391, $4.26 \mathrm{~mm}$ diameter, $0.4 \mu \mathrm{m}$ pore size, uncoated polycarbonate filters, Costar) at high density $\left(2.42 \times 10^{5}\right.$ cells $\left./ \mathrm{cm}^{2}\right)$. Cells were grown to confluency for 14-17 days and transepithelial electrical resistance (TEER) was measured using a WPI EVOM voltohmeter (World Precision Instruments, Stevenage, Hertfordshire, UK). Typical resistance values for Caco-2 cells were $>250 \Omega . \mathrm{cm}^{2}$.

\section{Transepithelial Transport Experiments}

Automated bi-directional transepithelial transport assays were performed using a Tecan Genesis Robotic workstation. Transport assays were performed 14-17 days post-seeding. Assays were performed in HBSS (Hanks buffered saline solution) at pH 7.4 in both apical and basal compartments. Transport plates were produced to allow the unidirectional (apical-to-basal, $P_{a-b}$ and basal-to-apical, $\left.P_{b-a}\right)$ permeability of each compound $(10 \mu \mathrm{M})$. Lucifer Yellow $(100 \mu \mathrm{M})$ 


\section{BDD-10-0113-R1}

was included in the transport buffer to allow post-assay determination of paracellular permeability, measured by spectrofluorometry (485-535). The extent of apical-to-basal and basal-to-apical transport was determined by HPLC MS/MS sample analysis for each drug compound. Apparent permeability $\left(P_{a p p} ; \times 10^{-6} \mathrm{~cm} \cdot \mathrm{s}^{-1}\right)$ was calculated for each compound in the apical-to-basal $\left(P_{a-b}\right)$ direction as described previously [10].

\section{Materials}

Cell culture media, Kreb's bicarbonate ringer (KBR) components and supplements were from Sigma (Poole, Dorset, UK), and tissue culture plastic flasks and culture plates were supplied by Costar (High Wycombe, UK). All other chemicals obtained from Sigma (Poole, Dorset, UK). All drug compounds were purchased from Sigma (Poole, Dorset, UK) or sourced from AstraZeneca's internal compound library.

\section{Statistics}

All data are expressed as mean \pm standard error of the mean (SEM) with $n$ representing the number of replicates in each experiment. The differences between mean data values were assessed using unpaired Student's T-tests. Tests for linear relationships between permeability values generated in the different tissue types were performed. Non-linear regressional analysis was performed to compare permeability values with known human Fabs data. All analysis performed using Prism 4 (Graphpad InStat, San Diego, California, USA). Statistical significance was reported at $\mathrm{P}<0.05$. 


\section{BDD-10-0113-R1}

\section{Results}

\section{Tissue viability and integrity}

Figure 1 displays the electrical timecourses for rat and human small intestine mounted in Ussing Chambers. (uneccessary duplication of methods deleted) At time 0 (following the 40 minute equilibration period), mean potential difference readings were $4.7 \pm 0.3 \mathrm{mV}$ and $5.7 \pm 0.5 \mathrm{mV}$ for rat and human tissue, respectively ( $n=128$ and 60 separate tissue sections, respectively). Shortcircuit current (Isc) was $161.8 \pm 19.2 \mu \mathrm{A} . \mathrm{cm}^{-2}$ for rat jejunum and $200.7 \pm 51.3 \mu \mathrm{A} . \mathrm{cm}^{-2}$ for human jejunum, with rat and human resistance $(\mathrm{R})$ values being $32.6 \pm 2.3 \Omega . \mathrm{cm}^{2}$ and $23.3 \pm 3.2$ $\Omega . \mathrm{cm}^{2}$, respectively ( $n=128$ and 60 separate tissue sections). Rat potential difference (PD) showed a steady decline over the 120 minute timecourse of each experiment, ending on $59 \%$ of the initial value. Human tissue was more resistant to decreasing PD as a reduced voltage difference was not evident until approximately 80 minutes, with final values being $75 \%$ of the initial value. For both rat and human tissue, short-circuit current initially rose during the first 40 (rat) to 60 (human) minutes after mounting the tissue in the chamber. Isc was maintained theron for the remainder of the timecourse. Conversely, $\mathrm{R}$ initially fell during the 40 minute equilibration period in both species. $\mathrm{R}$ in the human tissue then remained stable, with rat jejunal $\mathrm{R}$ showing a small rise towards 120 minutes.

(unneccessary duplication of methods removed) Figure 2 displays the response to CCh for both rat and human excised intestine in these studies. Rat tissue displayed a $29 \%$ increase in Isc in response to $\mathrm{CCh}$, from 124 to $159 \mu \mathrm{A} \cdot \mathrm{cm}^{-2}(n=15, \mathrm{P}<0.05)$. Human intestinal tissue showed a larger response with Isc increasing $50 \%$ following basolateral $\mathrm{CCh}$, from 122 to $183 \mathrm{~A} . \mathrm{cm}^{-2}$ $(n=20, \mathrm{P}<0.001)$.

In addition to real-time electrical indications of tissue viability and integrity, measuring the passive permeability of a paracellular molecule acts as more sensitive control for disrupted tissue integrity. Atenolol was chosen as a paracellular marker [14] amenable to analysis by LC 
MS/MS. As can be seen in Figure 3, atenolol flux remained linear for the timecourse of the experiments in both rat and human tissue, indicating maintained tissue integrity $\left(\mathrm{R}^{2}=0.984\right.$ and 0.996, respectively). There was no statistical difference between paracellular atenolol permeability in either species.

\section{Buffer conditions (constant gassing vs pre-saturation)}

The supply of oxygen to excised tissue sections is critical to maintaining viability and integrity once mounted in Ussing Chambers [11]. As transport logistics prevented constant gassing of human tissue in Kreb's bicarbonate ringer (KBR) from the Hospital to the laboratory, rat tissue was initially assessed to determine any impact on viability and integrity with regard to constantly gassed tissue vs pre-saturated buffer. Ice-cold KBR was used in both instances. Verapamil was used as a high permeability marker of transcellular permeability with atenolol used as a paracellular marker. KBR was either continuously perfused with carbogen or pre-saturated before being placed in a sealed, gas impermeable flask. Figure 4 (A) shows that there was no difference between either verapamil or atenolol absorptive permeability when tissue was transported in constantly gassed or pre-saturated, ice-cold KBR buffer. In addition Figures 4 (B), (C) and (D) indicate that electrical parameters were not affected, with PD, Isc and Rt values at time 0 effectively equal in both groups ( $n=3$ separate animals, NS).

\section{Rat jejunum, human jejunum and Caco-2 permeability}

The compounds selected for permeability experiments in rat jejunal tissue spanned a range of physicochemical space and human fraction absorbed values (Table 1). They include compounds subject to passive transcellular and paracellular movement, as well as active transport. The absorptive (mucosal to serosal) apparent permeability (Papp) values generated across the rat and human intestine are displayed in Table 2, alongside the human fraction absorbed values (Fabs), taken from various literature sources. The rank ordering between high-low permeability values in 


\section{BDD-10-0113-R1}

the rat jejunum and high-low human fraction absorbed values display a good agreement. The ordering does not appear to be as closely matched when looking at values generated in Caco-2 monolayers (Table 2).

The permeability of a number of the compounds investigated in rat intestine was also measured in the human jejunum sourced from pancreatoduodenectomy. The permeability values are shown in Table 2, displaying a rank ordering broadly in agreement with that of the rat intestinal tissue. When plotted against the Papp values generated in rat (Figure 5A), there is an excellent linear correlation $\left(\mathrm{R}^{2}=0.86, \mathrm{P}<0.05\right)$. However, the relationship does not follow the line of unity Compounds with Papp values $>20 \mathrm{~cm} / \mathrm{s}\left(\times 10^{-6}\right)$ in the rat intestine show considerably higher values than were measured the human intestine (Figure 5C). If the analysis only includes compounds below this Papp value in the rat, it is apparent that permeability is remarkably similar in both species (Figure 5B)

For compounds known to permeate predominantly via the paracellular route (i.e. atenolol, ranitidine) extremely low Papps are noted in Caco-2 cells, believed to result from the enhanced tight-junctional barrier in these cultured layers in relation to intact intestinal tissue [15]. This results in much poorer correlations when compared directly against the values generated in rat and human tissue. (paragraph moved and reference to old Figure 6 deleted)

The Papp values generated in Caco-2 monolayers, rat and human tissue can be related to human fraction absorbed (hFabs) whereby they are plotted on a logarithmic scale against the hFabs values. As can be seen in Figure 6A, there is a sigmoidal relationship $\left(R^{2}=0.73\right)$ between rat Papp and human Fabs, which mimics the output of research conducted by other groups with an alternative set of probe compounds [16]. The Papp values generated in the human small intestine with a subset of compounds also measured in that rat were plotted against hFabs values to produce the relationship shown in Figure 6B. The sigmoidal regression shows a marginally stronger correlation than was obtained using rat intestinal tissue $\left(\mathrm{R}^{2}=0.80\right)$. With the Caco-2 


\section{BDD-10-0113-R1}

values, a markedly different curve is observed (Figure 6C), due mainly to the low permeability values measured for the more hydrophilic compounds. The regression analysis indicates a strong correlation $\left(\mathrm{R}^{2}=0.92\right)$ with human Fabs.

In overlaying both human and rat Fabs curves, it can be seen that the relationship between Papp and human fraction absorbed is qualitatively similar for the training set of compounds used in this assay (Figure 6D) 


\section{BDD-10-0113-R1}

\section{Discussion}

The use of excised intestinal tissue in modified Ussing chambers has been developed for the study of permeability and absorption potential of NCEs. Previous investigations have defined explicit criteria for determining the viability of this excised tissue and it is recognised that maintained perfusion in situ is critical for maintaining viability ex vivo [11]. (duplication of methods information removed) The stripping process has previously been shown to have no detrimental impact on excised tissue [4] and was not specifically investigated in this study. The electrical parameters recorded in this study broadly agree with those measured in other laboratories for both rat and human tissue $[4,11,17]$ Active ion transport is maintained in tissue sections from both species, however the PDs do fall over the course of the experiment. Previous studies have shown that at 90 minutes, tissue damage can be observed in morphological assessments [10]. However, in the study by Soderholm et al [9], a drop in PD was noted prior to these signs of structural damage, indicating a reduction in ion transport, rather than a disruption of the tissue morphology. In the present study, chloride-related increases in Isc induced by the addition of CCh demonstrated that despite a fall in PD, the tissue sections remain metabolically active at the end of the incubation period.

Tissue resistance was found to be well maintained over the course of the experiment, although the relevance of this measure as an indicator of the extent of leak in a whole tissue section has been questioned in the past $[11,14]$. Small reductions in tissue integrity may not necessarily be reflected by changes in resistance. As such it is important to include a marker of paracellular permeability to assess leak upon post-experiment analysis. Atenolol, as a suitable molecule for this purpose $[1,14]$ was found to remain constant over the duration of the experiment and not to differ between human and rat tissues. In terms of tissue viability, human intestine excised during pancreatoduodenectomy retains the function of energy (ATP) dependent processes and displays maintained integrity over the course of an Ussing chamber experiment of up to 2 hours. Human tissue removed during pancreatoduodenectomy appears to show a greater degree of electrical 


\section{BDD-10-0113-R1}

stability than rat tissue, with the reduction in potential difference evident later in the experimental timecourse.

(duplication of results removed) The comparable rank ordering profile between rat and human Papp values described in our results has been previously reported for an alternate set of compounds [16] confirming the utility of human tissue from pancreatoduodenectomy in determining intestinal permeability of a range of drug compounds. In directly comparing the relationship between permeability in the rat and human intestine, a bias towards higher permeability values in the rat was evident. It has previously been suggested [2] that cross-species differences in the permeability of rapidly absorbed compounds are likely to result from differences in unstirred water layer (UWL) thickness, given the evidence that lipophilic compounds are influenced to a greater degree by the thickness of UWL [18]. This could therefore be responsible for the apparent bias towards higher rat jejunal permeability shown by the compounds with a rat Papp of $>20 \mathrm{~cm} / \mathrm{s}\left(\times 10^{-6}\right)$. Similar results have been reported previously, whereby non-linearity between rat Papp and Peff values were evident for higher permeability compounds, again suggested by the authors to be the result of difference in UWL [16]. In terms of permeability measurements across Caco-2 cells, it is recognised that limits are imposed by the presence of an UWL that is considerably thicker than is found in vivo [19-20]. In addition, the expression levels of certain active transport proteins may well differ between the cell system and intact intestinal tissue [8], therefore impacting on the permeability of substrates. As differences in UWL thickness exist, without active stirring of the cellular monolayers it is likely that the permeability of lipophilic compounds will be limited in this system. The reduction of UWL thickness by gas-lift in the Ussing chamber has been previously noted [20] and may indicate that a narrower UWL exists, allowing for higher permeability of rapidly absorbed compounds across intact tissue in this system when compared with the 'unstirred' Caco-2 monolayers. The UWL has been suggested to have little impact for slowly absorbed 


\section{BDD-10-0113-R1}

(hydrophilic) drugs where permeation across the cell membrane (or through the paracellular route) is likely to be the rate limiting step [21].

When directly comparing the permeability of rat and human jejunal tissue with the reported hFab values, the relationships are remarkably alike. This could indicate that rat jejunum is capable of predicting drug permeability across human jejunum and by extrapolation, producing a tentative prediction of human Fabs. However, there are caveats to be aware of when making these assessments. Differences in active transport or metabolism between the two species could result in significant differences in Fabs, which are unlikely to be predicted using a static regression curve relating Papp and hFabs, as shown here.

In comparing these results to previously published data, both in terms of tissue viability and permeability relationships, it is apparent that the system developed in our laboratory produces analogous results $[11,16]$. It is therefore apparent that these relationships hold true for a diverse range of compounds in terms of both physicochemical properties and mechanisms of permeability (passive versus active).

\section{Conclusions}

Surplus human small intestine removed during pancreatoduodenectomy has been found to remain viable and intact for use in Ussing Chamber investigation, displaying maintained ion transport and electrical resistance. Over a 2 hour timecourse in the chambers, both rat and human tissue sections retain ATP-hydrolysis and paracellular leak is not compromised, as determined by atenolol flux. Permeability measures across human tissue are comparable with data generated in excised rat intestinal sections, with excellent agreement in terms of rank-ordering. Caco-2 monolayers do not display a comparable permeability profile to the excised intestinal tissue, which may be related to differences in UWL thickness, paracellular permeability or transporter expression levels. In relating permeability to known human fraction absorbed values, rat and 
2

3

4

5

6

7

8

9

10

11

12

13

14

15

16

17

18

19

20

21

22

23

24

25

26

27

28

29

30

31

32

33

34

35

36

37

38

39

40

41

42

43

44

45

46

47

48

49

50

51

52

53

54

55

56

57

58

59

60

\section{BDD-10-0113-R1}

human excised tissue give qualitatively similar correlations. These results are analogous to previously published data generated using an alternative compound test set and tissue sourced from different surgeries. Human jejunal tissue excised during pancreatoduodenectomy is therefore useful in assessing compound permeability and absorption potential in the drug discovery setting. 


\title{
BDD-10-0113-R1
}

\begin{abstract}
Acknowledgments
The authors are extremely grateful to Tracey Randall, Jacqui Aitchison and Huw Bowen for all their assistance in gaining ethical approval for accessing pancreatoduodenectomy tissue, as well as in the setting up of study agreements and subsequent monitoring of the study. Stephanie Church and Joanne Shaw (CVGI DMPK, AstraZeneca, UK) conducted the Caco-2 studies described within and the authors thank them for providing this data. Iain Haslam would like to thank Professor Nick Simmons (Epithelial Research Group, Newcastle University, UK) for his useful discussions and insightful comments when reviewing this manuscript.
\end{abstract}


BDD-10-0113-R1

\section{References}

[1] Artursson, P., Karlsson, J. (1991). Correlation between oral drug absorption in humans and apparent drug permeability coefficients in human intestinal epithelial (caco-2) cells. Biochem. Biophys. Res. Commun. 175, 880-5.

[2] Jezyk, N., Rubas, W. \& Grass, G.M. (1992). Permeability characteristics of various intestinal regions of rabbit, dog, and monkey. Pharm. Res. 9, 1580-6.

[3] Ungell, A.L., Nylander, S., Bergstrand, S., Sjoberg, A. \& Lennernas, H. (1998). Membrane transport of drugs in different regions of the intestinal tract of the rat. J. Pharm. Sci. 87, 360-6, $10.1021 /$ js970218s.

[4] Nejdfors, P., Ekelund, M., Jeppsson, B. \& Westrom, B.R. (2000). Mucosal in vitro permeability in the intestinal tract of the pig, the rat, and man: Species- and region-related differences. Scand. J. Gastroenterol. 35, 501-7.

[5] Bajka, B.H., Gillespie, C.M., Steeb, C.B., Read, L.C. \& Howarth, G.S. (2003). Applicability of the ussing chamber technique to permeability determinations in functionally distinct regions of the gastrointestinal tract in the rat. Scand. J. Gastroenterol. 38, 732-41.

[6] Lucas, M.L., Blair, J.A., Cooper, B. \& Matty, A.J. (1975). Further investigations with pH microelectrodes into the jejunal microclimate in rat and man. Gut. 16, 844.

[7] van de Kerkhof, E.G., Ungell, A.L., Sjoberg, A.K., de Jager, M.H., Hilgendorf, C., de Graaf, I.A. \& Groothuis, G.M. (2006). Innovative methods to study human intestinal drug metabolism in vitro: Precision-cut slices compared with ussing chamber preparations. Drug Metab. Dispos. 34, 1893-902, 10.1124/dmd.106.011148.

[8] Hilgendorf, C., Ahlin, G., Seithel, A., Artursson, P., Ungell, A.L. \& Karlsson, J. (2007). Expression of thirty-six drug transporter genes in human intestine, liver, kidney, and organotypic cell lines. Drug Metab. Dispos. 35, 1333-40, 10.1124/dmd.107.014902.

[9] Hidalgo, M. (2010). Pancreatic Cancer. N. Engl. J. Med. 362, 1605-17

[10] Soderholm, J.D., Hedman, L., Artursson, P., Franzen, L., Larsson, J., Pantzar, N., Permert, J. \& Olaison, G. (1998). Integrity and metabolism of human ileal mucosa in vitro in the ussing chamber. Acta Physiol. Scand. 162, 47-56.

[11] Polentarutti, B.I., Peterson, A.L., Sjoberg, A.K., Anderberg, E.K., Utter, L.M. \& Ungell, A.L. (1999). Evaluation of viability of excised rat intestinal segments in the ussing chamber: Investigation of morphology, electrical parameters, and permeability characteristics. Pharm. Res. 16, 446-54.

[12] Dharmsathaphorn, K., Pandol, S.J. (1986). Mechanism of chloride secretion induced by carbachol in a colonic epithelial cell line. J. Clin. Invest. 77, 348-54, 10.1172/JCI112311.

[13] McEwan, G.T., Hirst, B.H. \& Simmons, N.L. (1994). Carbachol stimulates cl- secretion via activation of two distinct apical cl- pathways in cultured human T84 intestinal epithelial monolayers. Biochim. Biophys. Acta. 1220, 241-7. 
[14] Collett, A., Walker, D., Sims, E., He, Y.L., Speers, P., Ayrton, J., Rowland, M. \& Warhurst, G. (1997). Influence of morphometric factors on quantitation of paracellular permeability of intestinal epithelia in vitro. Pharm. Res. 14, 767-73.

[15] Artursson, P., Palm, K. \& Luthman, K. (2001). Caco-2 monolayers in experimental and theoretical predictions of drug transport. Adv. Drug Deliv. Rev. 46, 27-43.

[16] Lennernas, H. (1997). Human jejunal effective permeability and its correlation with preclinical drug absorption models. J. Pharm. Pharmacol. 49, 627-38.

[17] Corbett, C.L., Isaacs, P.E., Riley, A.K. \& Turnberg, L.A. (1977). Human intestinal ion transport in vitro. Gut. 18, 136-40.

[18] Winne, D. (1978). Dependence of intestinal absorption in vivo on the unstirred layer. Naunyn Schmiedebergs Arch. Pharmacol. 304, 175-81.

[19] Hidalgo, I.J., Hillgren, K.M., Grass, G.M. \& Borchardt, R.T. (1991). Characterization of the unstirred water layer in caco-2 cell monolayers using a novel diffusion apparatus. Pharm. Res. 8, 222-7.

[20] Karlsson, J., Artursson, P. (1992). A new diffusion chamber system for the determination of drug permeability coefficients across the human intestinal epithelium that are independent of the unstirred water layer. Biochim. Biophys. Acta. 1111, 204-10.

[21] Fagerholm, U., Lennernas, H. (1995). Experimental estimation of the effective unstirred water layer thickness in the human jejunum, and its importance in oral drug absorption. Eur $J$ Pharm Sci. 3, 247.

[22] McGinnity, D.F., Collington, J., Austin, R.P. \& Riley, R.J. (2007). Evaluation of human pharmacokinetics, therapeutic dose and exposure predictions using marketed oral drugs. Curr. Drug Metab. 8, 463-79.

[23] Zhao, Y.H., Le, J., Abraham, M.H., Hersey, A., Eddershaw, P.J., Luscombe, C.N., Butina, D., Beck, G., Sherborne, B., Cooper, I. \& Platts, J.A. (2001). Evaluation of human intestinal absorption data and subsequent derivation of a quantitative structure-activity relationship (QSAR) with the abraham descriptors. J. Pharm. Sci. 90, 749-84.

[24] Palm, K., Stenberg, P., Luthman, K. \& Artursson, P. (1997). Polar molecular surface properties predict the intestinal absorption of drugs in humans. Pharm. Res. 14, 568-71.

[25] Zhu, C., Jiang, L., Chen, T.M. \& Hwang, K.K. (2002). A comparative study of artificial membrane permeability assay for high throughput profiling of drug absorption potential. Eur. J. Med. Chem. 37, 399-407.

[26] Sugano, K., Hamada, H., Machida, M., Ushio, H., Saitoh, K. \& Terada, K. (2001). Optimized conditions of bio-mimetic artificial membrane permeation assay. Int. J. Pharm. 228, $181-8$.

[27] Kansy, M., Senner, F. \& Gubernator, K. (1998). Physicochemical high throughput screening: Parallel artificial membrane permeation assay in the description of passive absorption processes.

J. Med. Chem. 41, 1007-10, 10.1021/jm970530e. 


\section{BDD-10-0113-R1}

[28] Chiou, W.L., Barve, A. (1998). Linear correlation of the fraction of oral dose absorbed of 64 drugs between humans and rats. Pharm. Res. 15, 1792-5.

[29] Terao, T., Hisanaga, E., Sai, Y., Tamai, I., Tsuji, A. (1996). Active secretion of drugs from the small intestinal epithelium in rats by $\mathrm{P}$-glycoprotein functioning as an absorption barrier. $J$. Pharm. Pharmacol. 48, 1083-9

[30] Darnell, M., Karlsson, J.E., Owen, A., Hidalgo, I.J., Li, J., Zhang, W., Andersson, T.B. (2010). Investigation of the involvement of P-glycoprotein and multidrug resistance-associated protein 2 in the efflux of ximelagatran and its metabolites by using short hairpin RNA knockdown in Caco-2 cells. Drug. Metab. Dispos. 38, 491-7

[31] Yokooji, T., Yumoto, R., Nagai, J., Takano, M., Yokooji, T., Murakami, T. (2007). Role of intestinal efflux transporters in the intestinal absorption of methotrexate in rats. J. Pharm.

Pharmacol. 59, 1263-70 
BDD-10-0113-R1

\section{Figure 1.}

Changes in electrical parameters, $(\mathrm{A})$ potential difference $(\mathrm{mV}),(\mathrm{B})$ short-circuit current $\left(\mu \mathrm{A} . \mathrm{cm}^{-}\right.$

${ }^{2}$ ) and $(\mathrm{C})$ resistance $\left(\Omega . \mathrm{cm}^{2}\right)$, in rat (closed circles) and human (open circles) jejunum over a 160 minute period in Ussing Chambers.

\section{Figure 2.}

Changes in short-circuit current $\left(\mu \mathrm{A} . \mathrm{cm}^{-2}\right)$ across rat (closed circles) and human (open circles) jejunum, in response to $100 \mu \mathrm{M}$ basolateral carbachol stimulation following 160 minutes in Ussing Chambers.

\section{Figure 3.}

Flux of atenolol $(100 \mu \mathrm{M})$ across rat and human jejunum, mounted in Ussing chambers for 120 minutes. Linear regression indicates $\mathrm{R}^{2}$ values of 0.99 and 0.98 for atenolol flux across human and rat intestine, respectively.

\section{Figure 4.}

(A) Verapamil and atenolol permeability across rat jejunum mounted in Ussing chambers following transport in constantly perfused KBR (open bars) and pre-saturated KBR (closed bars). Comparison of electrical parameters (B) PD, (C) Isc and (D) resistance for across rat jejunum mounted in Ussing chambers following transport in constantly perfused KBR (open bars) and pre-saturated KBR (closed bars).

\section{Figure 5.}

(A) Correlation between rat and human jejunum apparent permeability (Papp, $\mathrm{cm} \cdot \mathrm{s}^{-1} \times 10^{-6}$ ), measured in vitro using Ussing chambers. Correlations are shown for compounds displaying a 


\section{BDD-10-0113-R1}

Papp of $<20 \mathrm{~cm} \cdot \mathrm{s}^{-1} \times 10^{-6}$ in rat jejunum (B) and $>20 \mathrm{~cm} \cdot \mathrm{s}^{-1} \times 10^{-6}$ in rat jejunum (C). Data are mean values generated using tissue from at least 3 separate rats or human donors.

\section{Figure 6.}

Relationship between drug permeability (Papp) measured in (A) rat jejunum, (B) human jejunum and (C) Caco-2 cell monolayers and the human fraction absorbed values as reported in the literature. An overlay of the 3 regression curves is displayed in (D). Papp values are the mean of measurements in tissue from at least 3 separate rats or human donors. 


\section{BDD-10-0113-R1}

Table 1. Physicochemical properties and fraction absorbed (Fabs) values for drug compound test set.

\begin{tabular}{|c|c|c|c|c|c|c|c|c|c|}
\hline \multirow[b]{2}{*}{ Compound } & \multirow[b]{2}{*}{ MW } & \multicolumn{2}{|c|}{ Fabs $(\%)$} & \multirow[b]{2}{*}{ cLogP } & \multirow[b]{2}{*}{$\log D$} & \multirow[b]{2}{*}{ PSA } & \multirow[b]{2}{*}{ HBD } & \multirow[b]{2}{*}{ HBA } & \multirow[b]{2}{*}{ HB } \\
\hline & & Human & Rat & & & & & & \\
\hline Acebutolol $^{\mathrm{A}}$ & 336.4 & 46 & 22 & 1.7 & -0.2 & 97 & 3 & 6 & 9 \\
\hline Atenolol $^{\mathrm{P}}$ & 266.3 & 50 & 19 & -0.1 & -1.7 & 92 & 4 & 5 & 9 \\
\hline Betaxolol $^{P}$ & 307.4 & 90 & 5 & 2.3 & 0.8 & 55 & 2 & 4 & 6 \\
\hline Bisoprolol $^{\mathrm{P}}$ & 325.5 & 46 & 46 & 1.8 & 0.4 & 64 & 2 & 5 & 7 \\
\hline Candesartan $^{P}$ & 440.5 & 15 & - & 5.2 & -1.9 & 114 & 2 & 9 & 11 \\
\hline Carvedilol $^{\mathrm{P}}$ & 406.5 & 43 & 9 & 4.0 & 3.6 & 78 & 3 & 6 & 9 \\
\hline Cetirizine $^{P}$ & 388.9 & 100 & 27 & 2.1 & 1.3 & 52 & 1 & 5 & 6 \\
\hline Cimetidine $^{\mathrm{A}}$ & 252.3 & 64 & 19 & 0.2 & 0.3 & 82 & 3 & 6 & 9 \\
\hline Ciprofloxacin $^{A}$ & 331.4 & 69 & - & -0.7 & -1.2 & 75 & 2 & 6 & 8 \\
\hline Diazepam $^{P}$ & 284.8 & 100 & - & 3.0 & 2.8 & 29 & - & 3 & 3 \\
\hline Famotidine $^{P}$ & 337.5 & 38 & 15 & -0.6 & -0.6 & 179 & 8 & 9 & 17 \\
\hline Hydrocortisone ${ }^{P}$ & 362.5 & 91 & - & 1.9 & - & 104 & 3 & 5 & 8 \\
\hline Indomethacin ${ }^{P}$ & 357.8 & 100 & 47 & 4.2 & 1.0 & 69 & 1 & 5 & 6 \\
\hline Ketanserin $^{P}$ & 395.4 & 81 & 90 & 3.0 & 2.2 & 71 & 1 & 6 & 7 \\
\hline Metoprolol $^{\mathrm{P}}$ & 267.4 & 95 & 100 & 1.5 & -0.3 & 55 & 2 & 4 & 6 \\
\hline Nadolol $^{P}$ & 309.4 & 31 & 5 & 0.4 & - & 91 & 4 & 5 & 9 \\
\hline Ondansetron $^{\mathrm{P}}$ & 293.4 & 86 & - & 2.7 & 1.7 & 30 & - & 4 & 4 \\
\hline Oxprenolol $^{\mathrm{P}}$ & 265.4 & 97 & - & 2.1 & 0.1 & 55 & 2 & 4 & 6 \\
\hline Pindolol $^{\mathrm{P}}$ & 248.3 & 100 & - & 1.7 & 0.5 & 60 & 3 & 4 & 7 \\
\hline Propranolol $^{\mathrm{P}}$ & 259.4 & 100 & 100 & 2.8 & 1.3 & 46 & 2 & 3 & 5 \\
\hline Quinidine $^{\mathrm{A}}$ & 324.4 & 80 & - & 2.8 & 2.2 & 43 & 1 & 4 & 5 \\
\hline Ranitidine $^{P}$ & 314.4 & 50 & 13 & 0.7 & -0.9 & 84 & 2 & 7 & 9 \\
\hline Sulfasalazine $^{A}$ & 398.4 & 12 & - & 3.9 & 0.5 & 148 & 3 & 9 & 12 \\
\hline Verapamil $^{\mathrm{A}}$ & 454.6 & 95 & 100 & 4.5 & 1.8 & 56 & - & 6 & 6 \\
\hline Melagatran $^{\mathrm{A}}$ & 429.5 & 5 & - & -0.8 & -1.4 & 159 & 6 & 9 & 15 \\
\hline Methotrexate $^{\mathrm{A}}$ & 454.4 & 20 & - & -0.5 & - & 212 & 7 & 13 & 20 \\
\hline Theophylline $^{\mathrm{P}}$ & 180.2 & 98 & 97 & 0.0 & -0.2 & 62 & 1 & 6 & 7 \\
\hline
\end{tabular}


BDD-10-0113-R1

Table 2. Apparent permeability (Papp, $P a-b$ ) values across Caco-2 cell monolayers, rat jejunum and human jejunum.

\begin{tabular}{|c|c|c|}
\hline $\begin{array}{c}\text { Rat } \\
\text { jejunum }\end{array}$ & $\begin{array}{c}\text { Human } \\
\text { jejunum }\end{array}$ & Сaco-2 \\
\hline
\end{tabular}

\section{Compound}

$\longrightarrow$

\section{Diazepam}

Propranolol

Verapamil

Ketanserin

Pindolol

Quinidine

Cetirizine

Indomethacin

Ciprofloxacin

Ondansetron

Hydrocortisone

Oxprenolol

Betaxolol

Theophylline

Metoprolol

Atenolol

Acebutolol

Bisoprolol

Methotrexate

Cimetidine

Nadolol

Famotidine

Melagatran

Candesartan

Ranitidine

Carvedilol

Sulfasalazine

\section{Papp $\left(\mathrm{cm} / \mathrm{s} \mathrm{x10}^{-6}\right)$}

\begin{tabular}{cc}
$\begin{array}{c}\text { Rank Order } \\
\text { (rat/human }\end{array}$ & $\begin{array}{c}\text { Human } \\
\text { Papp) }\end{array}$ \\
\hline
\end{tabular}

89.0

37.4

27.0

15.9

15.1

36.6

29.4

23.2

15.9

31.1

15.7

2.9

25.5

23.3

21.5

17.3

13.2

12.1

10.8

10.4

10.4

9.5

9.5

6.5

5.5

4.7

4.0

3.7

0.7
22.3
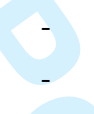

$\begin{array}{ll}- & 28.4\end{array}$

28.1

13.7

27.9

17.8

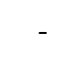

11.0

$$
0.6
$$

1.6

17.3

0.2

0.7

0.4

$$
0.4
$$

0.1

0.3

0.6

2.6

0.9
$1 / 1$

100

$2 / 2$

100

- 95

- 81

$3 / 3 \quad 100$

- $\quad 80$

$4 / 4 \quad 100$

$\begin{array}{ll}- & 100\end{array}$

$5 / 6 \quad 69$

$\begin{array}{ll}\text { - } & 86\end{array}$

$\begin{array}{ll}- & 91\end{array}$

-97
$-\quad 90$

- 90

-
$-\quad 98$

$6 / 5 \quad 95$

- 50

$7 / 7 \quad 46$

- 46

- 20

$8 / 8 \quad 64$

- 31

$\begin{array}{ll}- & 38\end{array}$

- 5

$9 / 10 \quad 15$

$10 / 9 \quad 50$

$11 / 11 \quad 43$

$12 / 12 \quad 12$

- = no data; the rank ordering between rat and human Papp values is also displayed; Human Fabs values taken from references $22-28$. 